\title{
Investigation of the correlation between odd oxygen and secondary organic aerosol in Mexico City and Houston
}

\author{
E. C. Wood ${ }^{1}$, M. R. Canagaratna ${ }^{1}$, S. C. Herndon ${ }^{1}$, T. B. Onasch ${ }^{1}$, C. E. Kolb ${ }^{1}$, D. R. Worsnop ${ }^{1}$, J. H. Kroll ${ }^{1, *}$, \\ W. B. Knighton ${ }^{2}$, R. Seila ${ }^{3}$, M. Zavala ${ }^{4}$, L. T. Molina ${ }^{4}$, P. F. DeCarlo ${ }^{5,6, *}$, J. L. Jimenez ${ }^{5,6,7}$, A. J. Weinheimer ${ }^{8}$, \\ D. J. Knapp ${ }^{8}$, B. T. Jobson ${ }^{9}$, J. Stutz ${ }^{10}$, W. C. Kuster ${ }^{11}$, and E. J. Williams ${ }^{11}$ \\ ${ }^{1}$ Aerodyne Research, Inc., Billerica, Massachusetts, USA \\ ${ }^{2}$ Department of Chemistry, Montana State University, Bozeman, Montana, USA \\ ${ }^{3}$ United States Environmental Protection Agency, Research Triangle Park, North Carolina, USA \\ ${ }^{4}$ Molina Center for Energy and the Environment, La Jolla, California, USA \\ ${ }^{5}$ Department of Atmospheric and Oceanic Sciences, University of Colorado, Boulder, Colorado, USA \\ ${ }^{6}$ Cooperative Institute for Research in the Environmental Sciences (CIRES), University of Colorado, Boulder, Colorado, USA \\ ${ }^{7}$ Department of Chemistry and Biochemistry, University of Colorado, Boulder, Colorado, USA \\ ${ }^{8}$ National Center for Atmospheric Research, Boulder Colorado, USA \\ ${ }^{9}$ Department of Civil and Environmental Engineering, Washington State University, Pullman, Washington, USA \\ ${ }^{10}$ Department of Atmospheric and Oceanic Sciences, University of California, Los Angeles, California, USA \\ ${ }^{11}$ NOAA Earth System Research Laboratory, Boulder, Colorado, USA \\ *now at: Department of Civil and Environmental Engineering, Massachusetts Institute of Technology, Cambridge, \\ Massachusetts, USA \\ ${ }^{* *}$ now at: Laboratory of Atmospheric Chemistry, Paul Scherrer Institute, Switzerland
}

Received: 14 January 2010 - Published in Atmos. Chem. Phys. Discuss.: 9 February 2010

Revised: 10 August 2010 - Accepted: 13 September 2010 - Published: 27 September 2010

\begin{abstract}
Many recent models underpredict secondary organic aerosol (SOA) particulate matter (PM) concentrations in polluted regions, indicating serious deficiencies in the models' chemical mechanisms and/or missing SOA precursors. Since tropospheric photochemical ozone production is much better understood, we investigate the correlation of odd-oxygen $\left(\left[\mathrm{O}_{\mathrm{x}}\right] \equiv\left[\mathrm{O}_{3}\right]+\left[\mathrm{NO}_{2}\right]\right)$ and the oxygenated component of organic aerosol (OOA), which is interpreted as a surrogate for SOA. OOA and $\mathrm{O}_{\mathrm{x}}$ measured in Mexico City in 2006 and Houston in 2000 were well correlated in air masses where both species were formed on similar timescales (less than $8 \mathrm{~h}$ ) and not well correlated when their formation timescales or location differed greatly. When correlated, the ratio of these two species ranged from $30 \mu \mathrm{g} \mathrm{m}^{-3} / \mathrm{ppm}$ (STP) in Houston during time periods affected by large petrochemical plant emissions to as high as $160 \mu \mathrm{g} \mathrm{m} \mathrm{m}^{-3} / \mathrm{ppm}$ in Mexico City, where typical values were near $120 \mu \mathrm{g} \mathrm{m}^{-3} / \mathrm{ppm}$. On several days in Mexico City, the $[\mathrm{OOA}] /\left[\mathrm{O}_{\mathrm{x}}\right]$ ratio decreased
\end{abstract}

by a factor of $\sim 2$ between 08:00 and 13:00 local time. This decrease is only partially attributable to evaporation of the least oxidized and most volatile components of OOA; differences in the diurnal emission trends and timescales for photochemical processing of SOA precursors compared to ozone precursors also likely contribute to the observed decrease. The extent of OOA oxidation increased with photochemical aging. Calculations of the ratio of the SOA formation rate to the $\mathrm{O}_{\mathrm{x}}$ production rate using ambient VOC measurements and traditional laboratory SOA yields are lower than the observed $[\mathrm{OOA}] /\left[\mathrm{O}_{\mathrm{x}}\right]$ ratios by factors of 5 to 15 , consistent with several other models' underestimates of SOA. Calculations of this ratio using emission factors for organic compounds from gasoline and diesel exhaust do not reproduce the observed ratio. Although not succesful in reproducing the atmospheric observations presented, modeling $P(\mathrm{SOA}) / P\left(\mathrm{O}_{\mathrm{x}}\right)$ can serve as a useful test of photochemical models using improved formulation mechanisms for SOA. 


\section{Introduction}

Numerous cities in the world struggle to attain air quality standards for ozone and fine particulate matter. The adverse impact of elevated concentrations of ozone and particulate matter on public health has been well documented and includes excess mortality counts (Izzotti et al., 2000), emergency room visits (WHO, 2003), exacerbation of asthma (McCreanor et al., 2007), and other negative health effects (Pope and Dockery, 2006). The outflow of elevated levels of ozone and PM from megacities impacts climate change as well. Ozone is a greenhouse gas and exerts a positive radiative forcing (i.e., warming effect). The uncertainties associated with the radiative forcings of aerosol (both direct and indirect) continue to comprise the largest source of uncertainty in the radiative forcings in climate models (Forster et al., 2007).

The science of tropospheric ozone formation was first investigated following the discovery of photochemical smog in LA in the late 1940s, and has matured greatly in the last 60 years. The rate of ozone production can be quantified by various methods (Cazorla and Brune, 2009; Kanaya et al., 2008; Thornton et al., 2002; Wood et al., 2009), and its non-linear dependence on its chemical precursors - volatile organic compounds (VOCs) and nitrogen oxides $\left(\mathrm{NO}_{\mathrm{x}}\right)$ - has been examined in several studies (Jaegle, 1999; Kleinman, 2005; Thornton et al., 2002). Although not complete, the chemical mechanisms through which VOC oxidation leads to ozone production have been elucidated through well-established laboratory techniques (Atkinson, 2000). Results from ozone photochemical models are used by policymakers to design air pollution mitigation measures such as state implementation plans (SIPs) in the U.S. Although some predictive models are accurate to within 30\% (e.g., Lei et al., 2007), serious knowledge gaps do remain (Hofzumahaus et al., 2009). Additionally, air quality models are often limited by the quality of emissions and meteorological input data.

In contrast, the underlying science of SOA formation is less mature. The chemical mechanisms that control SOA formation often involve larger organic molecules and more complex pathways and are far from fully understood (Hallquist et al., 2009). SOA formation is often studied under controlled conditions in smog chambers. These studies provide valuable insights into SOA formation mechanisms and PM yields. However, the conditions under which these experiments are conducted do not fully simulate atmospheric conditions. Since most chamber studies are limited to small numbers of precursor organic compounds, they may miss synergistic interactions among the numerous emitted organic compounds, their atmospheric oxidation products, and other atmospheric species. Several studies using traditional models (those in use before 2006) have predicted SOA concentrations that are low by an order of magnitude in both the polluted boundary layer (de Gouw et al., 2005; Kleinman et al., 2008; Volkamer et al., 2006) and the free troposphere
(Heald et al., 2005). A recent noteworthy study showed that semivolatile and intermediate volatility organic compounds may play a dominant role in SOA formation in urban locations (Robinson et al., 2007). Furthermore, there is disagreement over the importance of anthropogenic versus biogenic and biomass burning SOA precursors (de Gouw and Jimenez, 2009; de Gouw et al., 2009; Marley et al., 2009).

The apportionment of measured particulate organic carbon or OA mass into primary and secondary contributions has not been straightforward, with POA often being overestimated by the widely used EC-tracer method (Docherty et al., 2008; Zhang et al., 2005b), which is based on the ratio of organic aerosol to elemental carbon. Recent advances in organic aerosol analysis with rapid water-soluble organic carbon (WSOC) analysis and factor analysis of aerosol mass spectrometer (AMS) data has, however, provided new insights into the partitioning of OA into several components in diverse locations (Docherty et al., 2008; Hagino et al., 2007; Lanz et al., 2007; Sullivan et al., 2004; Zhang et al., 2005a). In particular, these analyses allow for the OA mass observed in ambient locations to be separated into contributions from a few key components. Globally, the oxygenated organic aerosol component (OOA) has been found to account for $64 \%$ to $95 \%$ of observed OA, with higher percentages observed at more rural sites (Zhang et al., 2007). Two broad subtypes of OOA, "low-volatility OOA" (LV-OOA) and "semi-volatile OOA" (SV-OOA), which differ from each other according to their volatility and extent of oxidation have also been identified (Jimenez et al., 2009). At most sites, the time trends, mass spectra, correlation of tracers, and comparison with SOA estimates from other techniques indicate that most or all the OOA component corresponds to SOA (Docherty et al., 2008; Herndon et al., 2008; Volkamer et al., 2006). Another common component of OA is hydrocarbonlike organic aerosol (HOA). The time trends and spectra of the HOA component, on the other hand, closely resemble primary organic aerosol (POA), likely from multiple combustion sources that cannot be separated due to the similarity of their mass spectra (Mohr et al., 2009; Ulbrich et al., 2009). Different types of OOA that correlate with inorganic tracers of different volatilities have been identified from AMS measurements (Lanz et al., 2007; Ulbrich et al., 2009). Biomass burning organic aerosol (BBOA) components have also been observed and characterized (Aiken et al., 2009).

In this paper, we extend the previously reported observations of OOA and $\mathrm{O}_{\mathrm{x}}$ in Mexico City (Herndon et al., 2008) during the MILAGRO 2006 campaign (Megacity Initiative: Local and Global Research Observations) and also compare to observations near Houston, Texas from the 2000 Texas Air Quality Study (TexAQS). The ratio of SOA production to $\mathrm{O}_{\mathrm{x}}$ production is calculated using VOC measurements (up to a carbon number of 12) from Mexico City and Houston using traditional laboratory SOA yields. Similar ratios for organic emissions from gasoline and diesel-fueled vehicles are calculated using known emission factors. These calculations 
do not accurately reflect the observed concentration ratios, but shed light on possible mechanisms. The observations of the correlations between OOA and $\mathrm{O}_{\mathrm{x}}$ may also be useful because it could allow for empirical predictions of SOA production in other locations from the better-characterized $\mathrm{O}_{\mathrm{x}}$ production predictions. Since these methods of characterizing SOA formation chemistry focus on predicted ratios rather than absolute concentrations of secondary pollutants, detailed knowledge of many aspects of meteorology, transport, and $[\mathrm{OH}]$ are unnecessary.

\section{Experimental methods}

\subsection{Aerodyne mobile laboratory, MILAGRO 2006}

Measurements of $\mathrm{NO}, \mathrm{NO}_{2}, \mathrm{NO}_{\mathrm{y}}\left(\mathrm{NO}_{\mathrm{y}} \equiv \mathrm{NO}+\mathrm{NO}_{2}+\right.$ $\mathrm{HNO}_{3}+$ organic nitrates $+2 * \mathrm{~N}_{2} \mathrm{O}_{5}+\mathrm{HONO}+$ particulate nitrate $+\ldots), \mathrm{HNO}_{3}, \mathrm{CO}, \mathrm{O}_{3}, \mathrm{C}_{2}-\mathrm{C}_{12}$ VOCs, black carbon, submicron organic aerosol, sulfate aerosol, and nitrate aerosol in Mexico City were made aboard the Aerodyne Mobile Laboratory (AML) (Kolb et al., 2004). During the MILAGRO 2006 campaign, the AML spent several days at numerous sites, including 9 days ( 8 March-20 March 2006) atop Pico de Tres Padres (PTP), a mountain within the Mexico City Valley. PTP is $\sim 10 \mathrm{~km}$ northeast of "T0" and $\sim 19 \mathrm{~km}$ southwest of "T1" - two of the ground "supersites". Due to its elevation ( $750 \mathrm{~m}$ above the basin elevation of $2.2 \mathrm{~km}$ ) and location within the Mexico City Metropolitan area, the measurements at PTP were not greatly impacted by local sources (i.e., sources within $6 \mathrm{~km}$ ), as described previously (Herndon et al., 2008; Wood et al., 2009). The AML also spent 3 days at T0 which is located within the core of the urban area and greatly affected by traffic and other emissions. A map of these sites in Mexico City can be found in Wood et al. (2009).

Details of most of the instrumentation used aboard the AML have been presented in a related manuscript (Wood et al., 2009) and only those most relevant to the analysis presented are described. Size-resolved non-refractory submicron particulate chemical composition was measured with an Aerodyne C-ToF aerosol mass spectrometer (Canagaratna et al., 2007). The AMS measures mass concentrations of non-refractory species in the $50 \mathrm{~nm}-1000 \mathrm{~nm}$ (vacuum aerodynamic diameter) size range, and thus provides a good representation of the total mass in the sub-micron accumulation mode. A collection efficiency of 0.5 was used for AMS measurements (estimated uncertainty of $20 \%$ ) aboard the AML as described in Wood et al. (2009). This is consistent with multiple previous AMS measurements from Mexico City (Aiken et al., 2009; DeCarlo et al., 2008; Kleinman et al., 2008; Paredes-Miranda et al., 2009; Salcedo et al., 2007; Salcedo et al., 2006). Black carbon mass loading was measured using a Thermo Electron Multi-Angle Aerosol Photometer (MAAP) instrument (Petzold and Schoenlinner, 2004). A mass specific absorption coefficient of $6.6 \mathrm{~m}^{2} / \mathrm{g}$ was used to convert from absorption to black carbon mass. With the exception of the canister VOC measurements, all AML data are presented as 1-min averages.

Ozone was measured with a 2BTech model 205M UV absorbance spectrometer ( $2 \%$ uncertainty). Benzene, toluene, $\mathrm{C}_{2}$-benzenes (sum of ethylbenzene and xylene isomers), $\mathrm{C}_{3}$ benzenes (sum of $\mathrm{C}_{9} \mathrm{H}_{12}$ isomers), acetone, acetaldehyde, and acetonitrile were continuously measured with a proton transfer reaction mass spectrometer (PTR-MS) (Rogers et al., 2006) with an uncertainty of $25 \%$. Whole air samples were collected in stainless steel canisters in Mexico City for subsequent quantification ( $30 \%$ uncertainty) of $\mathrm{C}_{2}-\mathrm{C}_{13}$ VOCs using gas chromatography with flame ionization detection (Seila et al., 2001, and see Supporting Information Table S1). $\mathrm{CO}, \mathrm{NO}_{2}$, and $\mathrm{HCHO}$ were measured using tunable infrared laser differential absorption spectrometers with an uncertainty of $15 \%$ (Wood et al., 2009).

\subsection{C-130 aircraft, MILAGRO 2006}

Organic aerosol was measured at various altitudes and distances from Mexico City aboard the NCAR/NSF C-130 aircraft using an Aerodyne high resolution time of flight AMS (DeCarlo et al., 2008; DeCarlo et al., 2006). The concentration and speciation measured in the aircraft during overflights of T0 were consistent with that observed at the ground site (DeCarlo et al., 2008, 2010). Ozone was measured on the C-130 using chemiluminescence with an accuracy of 5\% (Ridley et al., 1992), and $\mathrm{NO}_{2}$ was measured using photofragmentation via 395 -nm light-emitting diodes followed by chemiluminescence detection of NO, with a typical accuracy of $10 \% .12 \mathrm{~s}$ averages are presented.

\subsection{La Porte, TexAQS 2000}

Measurements in Houston during the 2000 Texas Air Quality Study (TexAQS) were made at La Porte, TX which is $40 \mathrm{~km}$ southeast of downtown Houston and $20 \mathrm{~km}$ south of the Houston Ship Channel, which contains a high density of petrochemical facilities. $\mathrm{C}_{2}-\mathrm{C}_{10}$ hydrocarbons were measured by two different instruments: gas chromatography with flame ionization detection for $\mathrm{C}_{2}-\mathrm{C}_{5}$ hydrocarbons and gas chromatography with mass spectrometric detection for $\mathrm{C}_{4}{ }^{-}$ $\mathrm{C}_{12}$ hydrocarbons, as described in detail elsewhere (Jobson et al., 2004; Kuster et al., 2004). Organic aerosol was measured with an Aerodyne quadrupole AMS (Canagaratna et al., 2007). Formaldehyde was measured with differential optical absorption spectrometry (Geyer et al., 2003). $\mathrm{NO}, \mathrm{NO}_{2}$, $\mathrm{NO}_{\mathrm{y}}, \mathrm{O}_{3}$, and $\mathrm{CO}$ were measured with NOAA instrumentation as described elsewhere (Thornton et al., 2003; Williams, 1997). Black carbon was measured with an aethelometer. All data are averaged on a ten-minute time-basis. 


\subsection{Positive Matrix Factorization of AMS data}

Positive matrix factorization (PMF) (Paatero and Tapper, 1994) was used to analyze unit mass resolution AMS spectra of organic aerosol using the methods described in Ulbrich et al. (2009). For both LaPorte and Mexico City datasets, HOA, OOA, and BBOA components dominate the observed OA composition. As in other urban sites (Zhang et al., 2007) mass spectral comparisons with reference spectra as well as correlations with external tracers, elemental composition, and diurnal cycles (Ulbrich et al., 2009) indicate that the HOA and OOA factors are largely dominated by primary and secondary aerosol sources. The BBOA component correlates well with gas phase acetonitrile and other biomass burning tracers and FLEXPART-predicted fire impacts (Aiken et al., 2010). Its mass spectrum is distinguished by high intensities of $\mathrm{m} / z 60$ and $\mathrm{m} / \mathrm{z} 73$ (Alfarra et al., 2007) which are mass spectral markers for the biomass burning tracer levoglucosan. Unit mass resolution spectra of BBOA contain features that are common to HOA and OOA component mass spectra as well. Thus, in cases where the time trend of BBOA is similar to either or both of these components, the HOA and OOA components extracted from unit mass resolution PMF analysis of AMS data can contain some residual contribution from BBOA. Aiken et al. (2008) have shown that this issue is less important in PMF analysis of high resolution (HR) AMS data because of the greater differences between the HR ions of the BBOA component and the HOA or OOA components.

PMF solutions are not necessarily unique particularly with respect to rotations (i.e. linear transformations of the factor time series and mass spectra). The rotational ambiguity of solutions in PMF can be explored with the FPEAK parameter (Ulbrich et al., 2009). The central solution obtained with PMF corresponds to an FPEAK value of 0 . Qualitatively, when compared with the FPEAK=0 solution, negative FPEAK values result in greater differences between the factor time series and increasing similarities between the factor mass spectra. The opposite is observed when comparing solutions from positive FPEAK values with FPEAK=0 solutions (Ulbrich et al., 2009). For the La Porte AMS dataset the PMF solution obtained with FPEAK=-0.3 was found to be the optimal solution with the least amount of residual BBOA contribution to the HOA and OOA components during known biomass burning dominated plumes observed during the campaign. For the Mexico City data, the FPEAK parameter was not as effective at reducing the residual contributions of BBOA to other components. Thus, the FPEAK $=0$ solution was reported by Herndon et al. (2008). In this analysis we use OOA/BBOA and HOA/BBOA ratios in biomass burning dominated plumes (i.e. time periods with minimal influence from photochemical activity and vehicle emissions) to apportion the residual primary BBOA related contributions to the HOA and OOA reported by Herndon et al. (2008). Thus, the BBOA mass concentrations reported in this manuscript are higher than those reported in Hern- don et al. (2008). This analysis also separates out a distinct "local organic aerosol" (LOA) factor, similar to that observed by Aiken et al. (2010) at the T0 site in Mexico City, from the total HOA factor reported by Herndon et al. (2008). Thus in this analysis the HOA/CO ratio observed at PTP is $7.9 \mu \mathrm{g} \mathrm{m}^{-3} / \mathrm{ppmv}$ compared to the $12 \mu \mathrm{g} \mathrm{m} \mathrm{m}^{-3} / \mathrm{ppmv}$ reported by Herndon et al. (2008). This updated value is very similar to those observed in Mexico City by others (Aiken et al., 2009; DeCarlo et al., 2010; Dzepina et al., 2009). In the absence of biomass burning plumes, the OOA values used in this analysis are typically about $0.4 \mu \mathrm{g} / \mathrm{m}^{3}$ lower than those used by Herndon et al. (2008), but the OOA/ $\mathrm{O}_{\mathrm{x}}$ slopes in this analysis differ from those reported by Herndon et al. (2008) by less than $20 \%$. Note also that the aerosol mass loadings $\left(\mu \mathrm{g} / \mathrm{m}^{3}\right)$ shown in Herndon et al. (2008) were expressed at ambient conditions while in this work the mass loadings for all datasets are converted to standard temperature and pressure $(273 \mathrm{~K}, 1 \mathrm{~atm})$ in order to facilitate comparison.

To ensure that air masses heavily influenced by biomass burning were excluded from the analysis, we filter the Mexico City data using the ratio of acetonitrile $\left(\mathrm{CH}_{3} \mathrm{CN}\right)$ to $\mathrm{CO}$, which is a common metric of biomass burning influence (de Gouw et al., 2006; Kleinman et al., 2008). The $\Delta[$ acetonitrile $] / \Delta[\mathrm{CO}]$ ratio was defined as ([acetonitrile] $200 \mathrm{pptv}) /([\mathrm{CO}]-135 \mathrm{ppbv})$, where $200 \mathrm{ppt}$ and $135 \mathrm{ppbv}$ were the average background concentrations of both species observed at night when the PTP site was above the shallow nocturnal boundary layer. Air masses greatly influenced by biomass burning typically have $\Delta$ [acetonitrile $] / \Delta[\mathrm{CO}]$ ratios between 1 and 7 (de Gouw 2006) while urban air masses are more typically in the range 0.1 to $0.3 \mathrm{pptv} / \mathrm{ppbv}$ (Kleinman et al., 2008; Knighton et al., 2007). Data in which $\Delta$ [acetonitrile] $/ \Delta[\mathrm{CO}]$ was greater than 1 were excluded from the $\Delta[\mathrm{OOA}] / \Delta\left[\mathrm{O}_{\mathrm{x}}\right]$ and $\Delta[\mathrm{OOA}] / \Delta\left[\mathrm{NO}_{3}^{-}\right]$correlations shown in Figs. 3 and 5. This excludes $8 \%$ of the Mexico City data.

\section{Results}

\subsection{Pollutant concentrations at PTP and Houston}

Figure 1 presents a time series of OOA, HOA, BBOA, $\mathrm{O}_{\mathrm{x}}$, $\mathrm{O}_{3}, \mathrm{NO}_{\mathrm{z}}\left(\left[\mathrm{NO}_{\mathrm{z}}\right] \equiv\left[\mathrm{NO}_{\mathrm{y}}\right]-\left[\mathrm{NO}_{\mathrm{x}}\right]\right), \mathrm{NO}_{\mathrm{y}}$, black carbon, and $\mathrm{CO}$ at the PTP site in Mexico City. The air masses observed at PTP have been described previously (Herndon et al., 2008; Wood et al., 2009). Typically, the concentrations of all species rose sharply starting at 09:00 local time due to upslope transport (Fig. 1), whereas the mixing layer depth usually did not grow to the elevation of PTP ( $750 \mathrm{~m}$ above the Mexico City plateau elevation) until $11: 00$ as observed at T0 (Shaw et al., 2007). The concentration of CO usually peaked near 11:00 and then decreased as the effect of dilution due to further rise of the boundary layer outpaced the flux of fresh emissions from below. The air masses observed at PTP were 


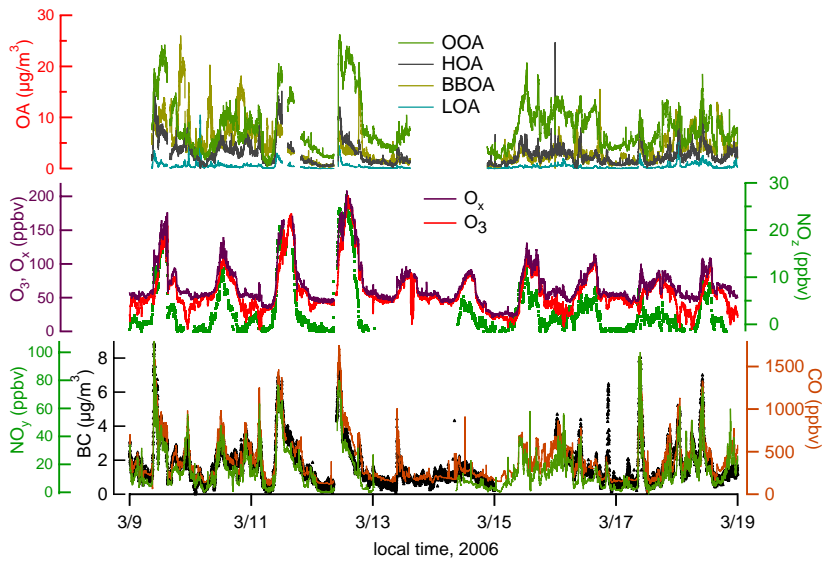

Fig. 1. Time series of OOA, $\mathrm{O}_{\mathrm{x}}$, and other species at Pico de Tres Padres. Gaps are from instrument maintenance.

usually characteristic of urban air with occasional influence from biomass burning. This statement is based primarily on the $\left[\mathrm{NO}_{\mathrm{y}}\right] /[\mathrm{CO}]$, [benzene]/[CO], and $\left[\mathrm{CH}_{3} \mathrm{CN}\right] /[\mathrm{CO}]$ ratios at T0 and PTP (Wood et al., 2009). The relatively constant scaling among the primary pollutants $\mathrm{NO}_{\mathrm{y}}$, black carbon, and $\mathrm{CO}$ is evident in Fig. 1. HOA concentrations correlate well with all three primary emissions tracers, as shown previously for $[\mathrm{HOA}] /[\mathrm{CO}]$ at PTP (Herndon et al., 2008) and other locations in Mexico City and elsewhere (e.g., Aiken et al., 2009; Takegawa et al., 2006; Volkamer et al., 2006; Zhang et al., 2005b).

The highest $\mathrm{OOA}$ and $\mathrm{O}_{3}$ values were observed on 11 and 12 March 2006, two days that were characterized by relatively stagnant air in the afternoon. These two days are used in this paper as a representative subset of mixed urban emissions from Mexico City, similar to their use in Wood et al. (2009).

Observations of the same chemical species in La Porte are shown in Fig. 2. Concentrations of $\mathrm{O}_{3}$ were similar to the PTP values - the peak values were above $200 \mathrm{ppbv}$, and on several days $\mathrm{O}_{3}$ exceeded $100 \mathrm{ppbv}$ for several hours. Average $\mathrm{NO}_{\mathrm{y}}$ concentrations were similar, but [CO] (and therefore $[\mathrm{CO}] /\left[\mathrm{NO}_{\mathrm{y}}\right]$ ) was much higher in Mexico City due to the high average $\mathrm{CO}$ emission factor from the motor vehicle fleet (Zavala et al., 2009). The occasional $\mathrm{NO}_{\mathrm{y}}$ "spikes" in Fig. 2 are from gas-fired power plant plumes and industrial $\mathrm{NO}_{\mathrm{x}}$ emissions. Prior to 4 September 2000, the main influences on the air observed at La Porte were urban emissions and petrochemical industry emissions. Back-trajectory analyses indicate that changes in the prevailing wind patterns between 4 and 8 September 2000 brought aged air masses to La Porte that had undergone long range transport and were significantly affected by biomass burning (Canagaratna et al., 2010). There is greater variation in the $\left[\mathrm{NO}_{\mathrm{y}}\right] /[\mathrm{CO}]$, $[\mathrm{BC}] /[\mathrm{CO}],\left[\mathrm{O}_{\mathrm{x}}\right] /\left[\mathrm{NO}_{\mathrm{z}}\right]$ and $[\mathrm{OOA}] /\left[\mathrm{O}_{\mathrm{x}}\right]$ values due to the greater variety of air masses observed at La Porte.

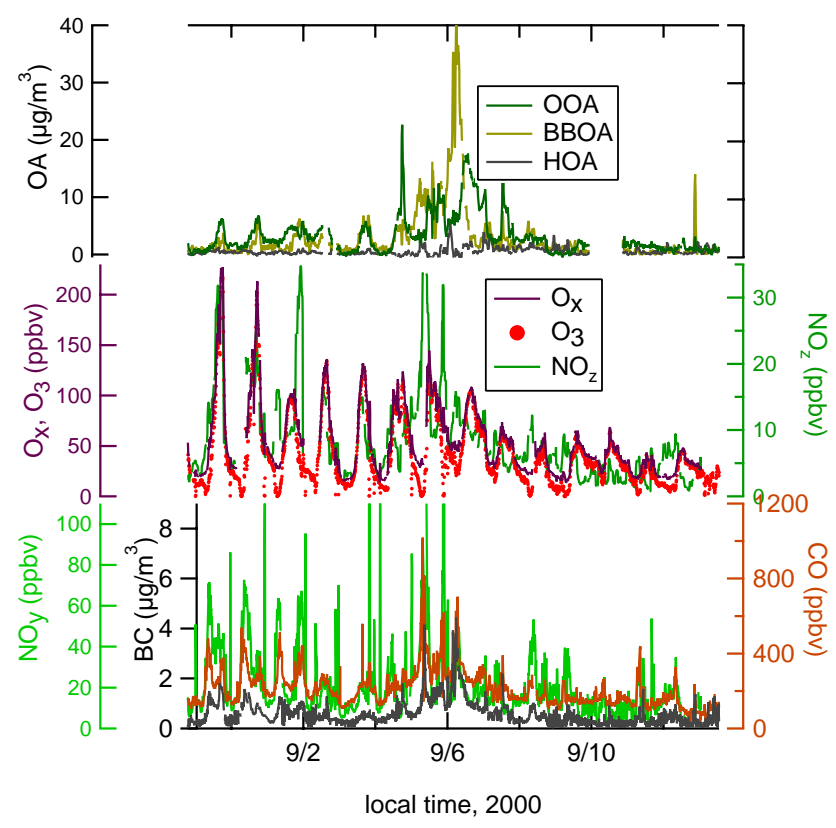

Fig. 2. Time series at La Porte, TX in 2000.

NCAR/NSF C-130 research flights on 10 March 2006 (RF3) and 29 March 2006 (RF12) consisted of segments both within the MCMA during the afternoon as well as segments sampling the aged MCMA outflow outside the MCMA (DeCarlo et al., 2010). RF3 was performed during a period in the campaign when biomass burning in and around Mexico City had a significant influence on the OA concentration measured aloft onboard the NCAR/NSF C-130. During RF12 the influence of biomass burning was greatly reduced due to frequent rain that had suppressed fire activity near the end of the month (Aiken et al., 2010; Fast et al., 2007).

Scatter plots between OOA and $\mathrm{O}_{\mathrm{x}}$ at PTP, La Porte, and the two $\mathrm{C}-130$ research flights are shown in Fig. 3. Data from 11 March and 12 March 2006 are colored separately in the top panel for distinction. Linear regression slopes were determined using a bi-variate linear fitting routine (Neri et al., 1989). The uncertainty in the slopes is typically less than $10 \%$. For the entire PTP data set, the slope of the graph of $[\mathrm{OOA}]$ versus $\left[\mathrm{O}_{\mathrm{x}}\right]$ (henceforth referred to as $\left.\Delta[\mathrm{OOA}] / \Delta\left[\mathrm{O}_{\mathrm{x}}\right]\right)$, is $119 \mu \mathrm{g} \mathrm{m} \mathrm{m}^{-3} / \mathrm{ppmv}$ with an $R^{2}$ of 0.68 . During RF3 aboard the C130 aircraft, $\Delta[\mathrm{OOA}] / \Delta\left[\mathrm{O}_{\mathrm{x}}\right]$ was $144 \mu \mathrm{g} \mathrm{m} \mathrm{m}^{-3} / \mathrm{ppmv}$ (STP) $\left(R^{2}=0.83\right)$, whereas $\Delta[\mathrm{OOA}] / \Delta\left[\mathrm{O}_{\mathrm{x}}\right]$ for the air masses observed during RF12 was $152\left(R^{2}=0.74\right)$. The large grouping of points from $\mathrm{RF} 12$ centered around $70 \mathrm{ppb} \mathrm{O}_{\mathrm{x}}$ and $3 \mu \mathrm{g} / \mathrm{m}^{3}$ OOA are data from a regional airmass that was likely influenced by rain on the previous day. In Houston, two distinct air masses were observed (Fig. 3, lowest panel). A slope of $30\left(R^{2}=0.54\right)$ was observed between 26 August and 4 September 2000 when the site sampled a combination of urban and petrochemical emissions. A slope of $101\left(R^{2}=0.41\right)$ was observed between 4 


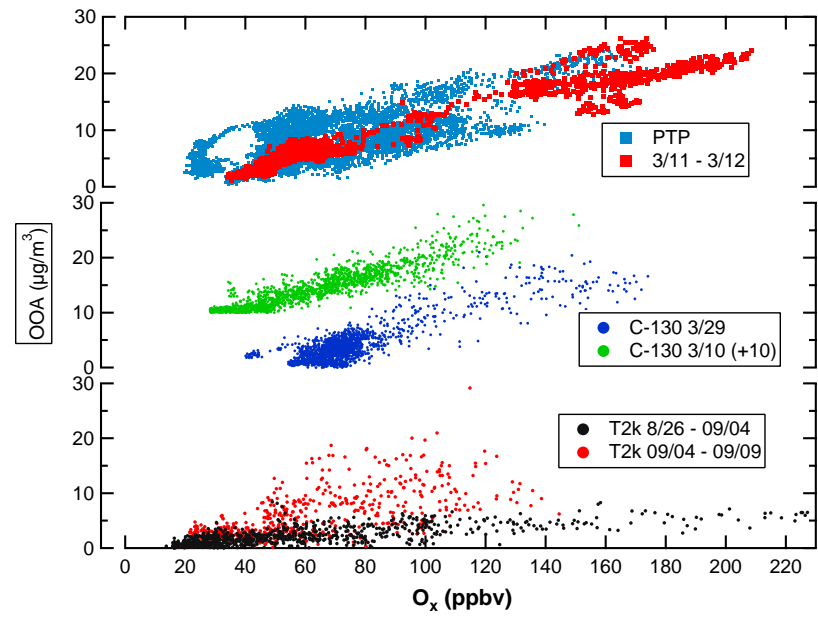

Fig. 3. Correlations of OOA with $\mathrm{O}_{\mathrm{x}}$ at PTP (top panel; 11 days, 1 min averages), two research flights (RF12 on 3/29 and RF3 on 3/10) aboard the C-130 aircraft in Mexico City (middle panel: 12$\mathrm{s}$ averages, green points are offset $10 \mu \mathrm{g} / \mathrm{m}^{3}$ ), and La Porte, Texas (bottom panel: $10 \mathrm{~min}$ averages, divided into two time periods).

and 8 September 2000. The underlying reasons for the large range in the $\Delta[\mathrm{OOA}] / \Delta\left[\mathrm{O}_{\mathrm{x}}\right]$ and correlation values observed are discussed in Sect. 4. OOA and $\mathrm{O}_{3}$ (rather than $\mathrm{O}_{\mathrm{x}}$ ) are not as well correlated since $\mathrm{NO}_{2}$ can account for a variable and sometimes large portion of $\mathrm{O}_{\mathrm{x}}$. At PTP, $\mathrm{NO}_{2}$ accounted for $20 \%$ to $50 \%$ of $\mathrm{O}_{\mathrm{x}}$ during the morning and usually less than $10 \%$ during the rest of the day.

\subsection{Subcomponents of OOA at PTP}

The PMF analysis of the organic aerosol data from PTP produced two classes of OOA that have been classified as "semi-volatile OOA" (SV-OOA) and "low-volatility OOA" (LV-OOA) according to their relative degree of oxidation (Jimenez et al., 2009; Ng et al., 2010). The sum of these two components is equal to total OOA. The mass spectra of the components show that LV-OOA is more oxidized than SV-OOA (Aiken et al., 2008). Similar subtypes of OOA have also been observed in other field studies (Jimenez et al., 2009; Lanz et al., 2007, 2009; Ng et al., 2010). These studies indicate that the LV-OOA component is also less volatile than the SV-OOA component (Lanz et al., 2007; Ulbrich et al., 2009). The LV-OOA and SV-OOA data from 11 and 12 March at PTP are shown in Fig. 4. The morning increase in total $[\mathrm{OOA}]$ is largely due to increases in [SV$\mathrm{OOA}]$, whereas [LV-OOA] accounts for a larger fraction of total OOA as the air becomes increasingly photochemically aged. The lowest values of $[\mathrm{LV}-\mathrm{OOA}] /[\mathrm{OOA}]$ were $\sim 0.35$ to 0.4 and occurred when slightly aged air first reached PTP between 08:00 and 11:00. By late afternoon, when the absolute LV-OOA concentrations were highest, the LV-OOA fraction had increased to 0.5-0.6. At night, when the mixing layer was below PTP and the lowest absolute concentrations of

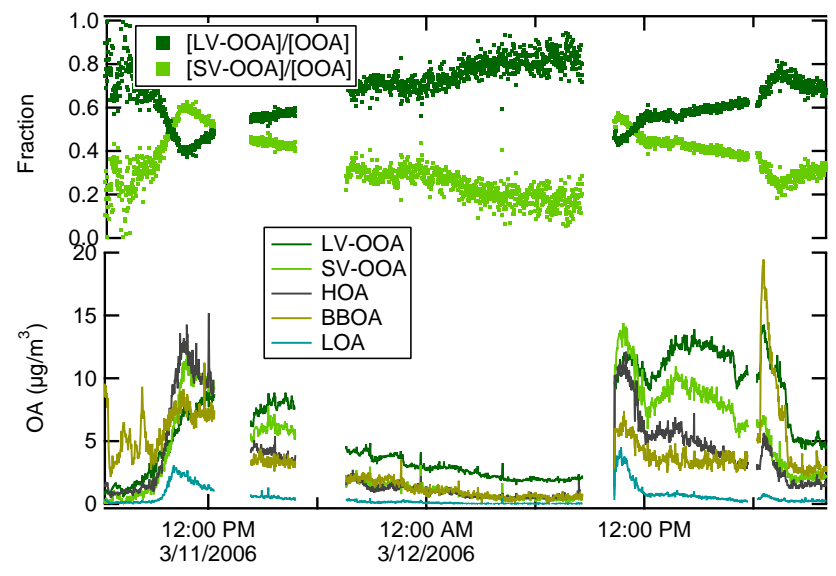

Fig. 4. Time series of the OA PMF components (lower graph), and fractional contribution of LV-OOA and SV-OOA to total OOA (upper graph) at PTP on 11 and 12 March 2006.

OOA were observed, the LV-OOA fraction was equal to 0.8 - consistent with the highly aged character of the air in the residual layer.

The correlations of the individual LV-OOA and SV-OOA components with $\mathrm{O}_{\mathrm{x}}$ and nitrate aerosol at PTP during 11 and 12 March 2006 are shown in Fig. 5. During these two days the correlation plots show a decrease in $\Delta \mathrm{OOA} / \Delta \mathrm{O}_{\mathrm{x}}$ with time of day. A similar decrease in $\Delta \mathrm{OOA} / \Delta \mathrm{O}_{\mathrm{x}}$ with photochemical age (which tends to increase with both time of day and ambient temperature) was presented in Herndon et al. (2008). Figure 5 shows that the decrease in $\Delta \mathrm{OOA} / \Delta \mathrm{O}_{\mathrm{x}}$ on 11 and 12 March 2006 was due to the variation in SV-OOA and not LV-OOA. The $\Delta \mathrm{SV}-\mathrm{OOA} / \Delta \mathrm{O}_{\mathrm{x}}$ slope decreased from $105 \mu \mathrm{g} \mathrm{m}^{-3} / \mathrm{ppmv}$ between 09:00 and 11:00 to $62 \mu \mathrm{g} \mathrm{m}^{-3} / \mathrm{ppmv}$ in the afternoon - almost a factor of two decrease. LV-OOA and $\mathrm{O}_{\mathrm{x}}$ were well correlated throughout both days $\left(R^{2}=0.96\right)$, with a slope that increased slightly in the afternoon, though not far from a value of $64 \mu \mathrm{g} \mathrm{m}^{-3} / \mathrm{ppm}$. There is no observed decrease in $\Delta \mathrm{LV}-\mathrm{OOA} / \Delta \mathrm{O}_{\mathrm{x}}$ with photochemical age or temperature, unlike the decrease observed in $\Delta \mathrm{OOA} / \Delta \mathrm{O}_{\mathrm{x}}$ with photochemical age (Herndon et al., 2008). Similar slopes between LV-OOA and SV-OOA with $\mathrm{O}_{\mathrm{x}}$ are observed for the entire PTP dataset $\left(R^{2}=0.61\right.$ for $\Delta[\mathrm{LV}-\mathrm{OOA}] / \Delta\left[\mathrm{O}_{\mathrm{x}}\right], R^{2}=0.29$ for $\left.\Delta[\mathrm{SV}-\mathrm{OOA}] / \Delta\left[\mathrm{O}_{\mathrm{x}}\right]\right)$. This degree of correlation is similar to that observed near Zurich, in which the $R^{2}$ for $\Delta \mathrm{LV}$ $\mathrm{OOA} / \Delta \mathrm{O}_{\mathrm{x}}$ was 0.51 (Lanz et al., 2007). SV-OOA correlated well with nitrate aerosol $\left(R^{2}=0.96\right.$ on 11 and 12 March 2006), similar to AMS observations in Pittsburgh (Ulbrich et al., 2009) and Switzerland (Lanz et al., 2007) and to correlations of particulate water-soluble organic carbon with nitrate aerosol observed at the T1 site in Mexico City (Hennigan et al., 2008). Since gas-phase nitric acid $\left(\mathrm{HNO}_{3}\right)$ concentrations are usually much lower than nitrate aerosol concentrations in Mexico City, SV-OOA also correlates well with the sum of aerosol nitrate and $\mathrm{HNO}_{3}$ (not shown). 


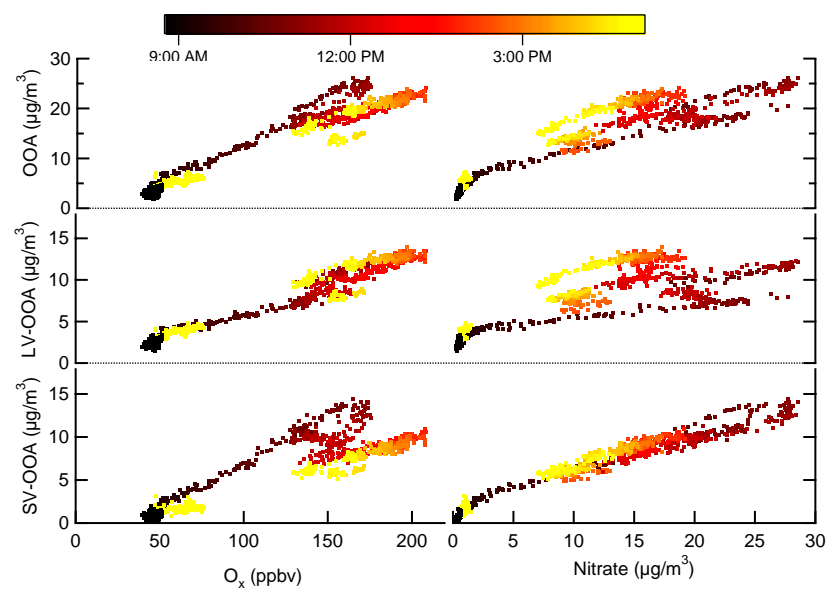

Fig. 5. Correlation of total OOA, LV-OOA and SV-OOA with $\mathrm{O}_{\mathrm{x}}$ and aerosol nitrate on 11 and 12 March 2006 at PTP (colored by time of day).

\section{Discussion}

In order to further understand the observed correlations in Mexico City and Houston, we present a simple model that calculates the ratio of SOA formation to $\mathrm{O}_{\mathrm{x}}$ production based on VOC measurements, $\mathrm{OH}$ rate constants, and organic aerosol yields.

\section{1 $\mathrm{O}_{\mathrm{x}}$ and SOA production}

Secondary organic aerosol formation is the result of gasparticle partitioning of low-volatility compounds formed by the atmospheric oxidation of VOCs. Since $\mathrm{O}_{\mathrm{x}}$ is also formed as a by-product of VOC oxidation and both $\mathrm{SOA}$ and $\mathrm{O}_{\mathrm{x}}$ have long lifetimes $(>12 \mathrm{~h}$ ), it is tempting to expect that SOA and $\mathrm{O}_{\mathrm{x}}$ concentrations should be correlated to some extent. Both ozone production and SOA formation can be thought to be initiated by the oxidation of VOCs with the hydroxyl radical $(\mathrm{OH})$. Consider the oxidation of an alkane (RH):

$\mathrm{RH}+\mathrm{OH} \rightarrow \mathrm{R}+\mathrm{H}_{2} \mathrm{O}$

$\mathrm{R}+\mathrm{O}_{2}+\mathrm{M} \rightarrow \mathrm{RO}_{2}+\mathrm{M}$

$\mathrm{RO}_{2}+\mathrm{NO} \rightarrow \mathrm{RO}+\mathrm{NO}_{2}$

$\mathrm{RO}+\mathrm{O}_{2} \rightarrow \mathrm{R}^{\prime} \mathrm{O}+\mathrm{HO}_{2}$

$\mathrm{HO}_{2}+\mathrm{NO} \rightarrow \mathrm{OH}+\mathrm{NO}_{2}$

$2 \mathrm{NO}_{2}+2 \mathrm{O}_{2}+\mathrm{h} v \rightarrow 2 \mathrm{NO}+2 \mathrm{O}_{3}$

Net: $\mathrm{RH}+4 \mathrm{O}_{2} \rightarrow \mathrm{R}^{\prime} \mathrm{O}+2 \mathrm{O}_{3}+\mathrm{H}_{2} \mathrm{O}$

In the above reaction sequence, $\mathrm{R}$ is an alkyl radical (e.g., $\mathrm{CH}_{3} \cdot$ ), $\mathrm{RO}_{2}$ is an organic peroxy radical (e.g., $\mathrm{CH}_{3} \mathrm{O}_{2}$ ), $\mathrm{RO}$ is an alkoxy radical, and $\mathrm{R}^{\prime} \mathrm{O}$ is a carbonyl. The secondary oxygenated organic compound (carbonyl or aldehyde) produced by this reaction sequence (such as $\mathrm{HCHO}$ ) can undergo further oxidation and in some cases photolysis to produce more ozone, until all the carbon in the initial VOC is either ultimately oxidized to $\mathrm{CO}_{2}$ or processes occur that remove the organic carbon from active gas-phase oxidation (e.g. deposition, aerosol formation).

For some organic compounds, the atmospheric oxidation proceeds solely in the gas phase, as depicted above. For other VOCs, the oxidation products formed have a low enough vapor pressure that they partition into aerosol particulate matter. The results of several laboratory SOA studies have suggested that the fate of the $\mathrm{RO}_{2}$ radical is key to determining the aerosol formation yield (Kroll and Seinfeld, 2008). Thus the rates of both ozone production and secondary organic aerosol formation are intimately connected to the rate of VOC oxidation.

\subsubsection{Formulation of $P\left(\mathbf{O}_{\mathbf{x}}\right)$}

A common method of expressing the rate of gross $\mathrm{O}_{\mathrm{x}}$ production is to equate it to the sum of the rates of Reactions (R3) and (R5):

$P\left(\mathrm{O}_{\mathrm{x}}\right)=\sum k_{R_{i} \mathrm{O}_{2}+\mathrm{NO}}\left[R_{i} \mathrm{O}_{2}\right][\mathrm{NO}]+k_{\mathrm{HO}_{2}+\mathrm{NO}}\left[\mathrm{HO}_{2}\right][\mathrm{NO}]$

Calculation of $\mathrm{O}_{\mathrm{x}}$ production rates using Eq. (1) requires measurements of $\mathrm{HO}_{2}$ and speciated organic peroxy radicals $\left(\mathrm{RO}_{2}\right)$, which are rarely available in field studies. Equation (2) shows a common alternative formulation of the rate of $\mathrm{O}_{\mathrm{x}}$ production, where $P\left(\mathrm{O}_{\mathrm{x}}\right)$ is related to the rate of the oxidation of VOCs by $\mathrm{OH}$ (usually the rate limiting step), producing peroxy radicals (Kleinman, 2005; Rosen et al., 2004):

$P\left(\mathrm{O}_{\mathrm{X}}\right)=\sum_{i} k_{i}[\mathrm{OH}]\left[\mathrm{VOC}_{i}\right]\left(a_{i} F_{i}\right)$

where $a_{i}=$ the number of $\mathrm{HO}_{2}$ and $\mathrm{RO}_{2}$ radicals propagated from each $\mathrm{OH}+\mathrm{VOC}$ reaction (2 for the reaction sequence $1-7)$, and $F_{i}=$ the fraction of $\mathrm{RO}_{2}$ radicals that oxidize NO to $\mathrm{NO}_{2}$.

Peroxy radicals can also be formed by mechanisms other than the oxidation of VOCs by OH, e.g. photolysis of oxygenated VOCs and ozonolysis of alkenes. Additional terms can be included in Eq. (2) to account for these processes; the most important is usually photolysis of formaldehyde (Volkamer et al., 2010; Wood et al., 2009). Based on $\mathrm{OH}$ estimates by Wood et al. (2009) and OH measurements (Dusanter et al., 2009; Shirley et al., 2006) in Mexico City combined with our measurements of HCHO, we estimate that ignoring the peroxy radicals formed from $\mathrm{HCHO}$ photolysis when using Eq. (2) leads to an underestimate of $P\left(\mathrm{O}_{\mathrm{x}}\right)$ by approximately $15 \%$. Disregarding these additional terms simplifies later equations (i.e., Eq. 4). Equation (2) also assumes that $\mathrm{HO}_{2}$ reacts solely with $\mathrm{NO}$ (see Supporting Information). This is the same formulation for $P\left(\mathrm{O}_{\mathrm{x}}\right)$ as used in 
Rosen et al. (2004) and very similar to those presented in previous studies (Kleinman, 2005; Tonnesen and Dennis, 2000), though different variables have been used - in particular, " $a$ " is used in Eq. (2) instead of the " $Y$ " used by Kleinmann et al. (2005) in order to avoid confusion with aerosol yields.

The value of $F$ in Eq. (2) is determined by the relative rates of Reaction (R3) and competing pathways for the peroxy radical reactions, including self reaction, reaction with $\mathrm{HO}_{2}$, the association with $\mathrm{NO}_{2}$ to form peroxynitrates (such as peroxyacetyl nitrate - PAN), and the association with $\mathrm{NO}$ to form alkyl nitrates. As such, the value of $F$ depends on the identity of the organic moiety " $R$ " of each peroxy radical, since the alkyl nitrate yield increases with carbon number (Arey et al., 2001). The $\mathrm{NO}_{\mathrm{x}}$-dependence of ozone production is implicit since $[\mathrm{OH}]$ is strongly affected by $\left[\mathrm{NO}_{\mathrm{x}}\right]$.

\subsubsection{Formulation of $P(\mathrm{SOA})$}

By assuming that the predominant mechanism that initiates SOA formation is the oxidation of VOCs (or more accurately "organic vapors") by reaction with $\mathrm{OH}$, an SOA "production rate" $P(\mathrm{SOA})$ can be expressed as

$$
P(\mathrm{SOA})=\sum_{i} k_{i}[\mathrm{OH}]\left[\mathrm{VOC}_{i}\right] y_{i}
$$

where $y_{i}$ are the SOA formation yields. These yields are a function of several reaction conditions, including temperature, $\left[\mathrm{NO}_{\mathrm{x}}\right]$ and the aerosol phase onto which the condensing organic compounds partition (Kroll and Seinfeld, 2008).

The calculated ratio of the formation rates of SOA and $\mathrm{O}_{\mathrm{x}}$ is given by Eq. (4):

$$
P(\mathrm{SOA}) / P\left(\mathrm{O}_{\mathrm{x}}\right)=\frac{\sum_{i} k_{i}\left[\mathrm{VOC}_{i}\right] y_{i}}{\sum_{i} k_{i}\left[\mathrm{VOC}_{i}\right] a_{i} F_{i}}
$$

Since the $\mathrm{OH}$ terms have conveniently cancelled out, Eq. (4) can be evaluated using the measurements of VOCs (in Mexico City and La Porte) and the laboratory-determined values for $k, y, a$, and $F$. For this analysis, we compare the ratio of production rates to the concentration ratios $[\mathrm{OOA}] /\left[\mathrm{O}_{\mathrm{x}}\right]$. These are, of course, different quantities. Measured concentrations of secondary species like $\mathrm{O}_{\mathrm{x}}$ and OOA at a stationary site are determined by the underlying chemical and physical processes that have occurred in the air masses observed, which may have several sources of origin (possibly with different precursor emission profiles). If all transport terms are ignored (including the dilution caused by a growing boundary layer), then the ratio of the change in the SOA and $\mathrm{O}_{\mathrm{x}}$ concentrations over the time period $\mathrm{t} 1$ and $\mathrm{t} 2$ can be expressed by Eq. (5):

$$
\frac{[\mathrm{SOA}]_{\mathrm{t} 2}-[\mathrm{SOA}]_{\mathrm{t} 1}}{\left[\mathrm{O}_{\mathrm{x}}\right]_{\mathrm{t} 2}-\left[\mathrm{O}_{\mathrm{x}}\right]_{\mathrm{t} 1}}=\frac{\int_{\mathrm{t} 1}^{\mathrm{t} 2} P(\mathrm{SOA}) d t-\int_{\mathrm{t} 1}^{\mathrm{t} 2} L(\mathrm{SOA}) d t}{\int_{\mathrm{t} 1}^{\mathrm{t} 2} P\left(\mathrm{O}_{\mathrm{x}}\right) d t-\int_{\mathrm{t} 1}^{\mathrm{t} 2} L\left(\mathrm{O}_{\mathrm{x}}\right) d t}
$$

where $P$ and $L$ are the production and loss rates, respectively, and $[\mathrm{OOA}]_{\mathrm{t} 1}$ and $\left[\mathrm{O}_{\mathrm{x}}\right]_{\mathrm{t} 1}$ are the initial concentrations at $\mathrm{t} 1$. If the loss terms are negligibly small and the production rates constant, then Eq. (5) can be simplified to Eq. (6):

$\frac{\Delta[\mathrm{SOA}]}{\Delta\left[\mathrm{O}_{\mathrm{x}}\right]} \approx \frac{P(\mathrm{SOA})}{P\left(\mathrm{O}_{\mathrm{x}}\right)}$

In addition to the assumptions made above, Eqs. (5) and (6) assume that horizontal transport has no effect and also ignore the dilution caused by the rise of the boundary layer (during which there is mixing with air above). There are important caveats regarding this last assumption, since [SOA] and $\left[\mathrm{O}_{\mathrm{x}}\right]$ are not zero in the air aloft. Typical "background" values of $[\mathrm{OOA}]$ and $\left[\mathrm{O}_{\mathrm{x}}\right]$ observed at PTP at night (when the site was above the nocturnal boundary layer) were between $1 \mu \mathrm{g} / \mathrm{m}^{3}$ to $2 \mu \mathrm{g} / \mathrm{m}^{3}$ for OOA and 40 to $50 \mathrm{ppbv}$ for $\mathrm{O}_{\mathrm{x}}$. Aircraft data (Fig. 3b) recorded at various altitudes show similar background $\mathrm{O}_{\mathrm{x}}$ values and OOA values ranging from 0 to $3 \mu \mathrm{g} / \mathrm{m}^{3}$ depending on the age and history of the air masses. The $\Delta[\mathrm{OOA}] / \Delta\left[\mathrm{O}_{\mathrm{x}}\right]$ values (defined as the slope of the graph of $[\mathrm{OOA}]$ vs. $\left[\mathrm{O}_{\mathrm{x}}\right]$ ) are not affected by dilution with fixed concentrations of OOA and $\mathrm{O}_{\mathrm{x}}$, but this is not always the case (see further discussion in Sect. 4.5). Furthermore, the partitioning of semivolatile OA is affected by dilution and temperature. The calculations described henceforth do not predict absolute $\mathrm{O}_{\mathrm{x}}$ or SOA concentrations, nor do they truly predict the ratio of concentrations at any given time (a chemical transport model would be required for such predictions). Nevertheless, the comparison of calculated $P(\mathrm{SOA}) / P\left(\mathrm{O}_{\mathrm{x}}\right)$ with observed $\Delta[\mathrm{OOA}] / \Delta\left[\mathrm{O}_{\mathrm{x}}\right]$ serves as a useful test of our general understanding of SOA and $\mathrm{O}_{3}$ formation.

The loss mechanisms for $\mathrm{O}_{\mathrm{x}}$ include the photolysis of $\mathrm{O}_{3}$ and subsequent reaction of the $\mathrm{O}\left({ }^{1} \mathrm{D}\right)$ product with water vapor, the oxidation of $\mathrm{NO}_{2}$ to $\mathrm{HNO}_{3}$ or peroxy nitrates such as peroxyacetyl nitrate (PAN), and other reactions. During the afternoon of 12 March at PTP, the oxidation of $\mathrm{NO}_{2}$ to form $\mathrm{NO}_{\mathrm{z}}$ compounds $\left(\mathrm{HNO}_{3}\right.$, organic nitrates, etc.) was the single largest loss process, accounting for roughly half of the total $\mathrm{O}_{\mathrm{x}}$ loss (Wood et al., 2009). The total $\mathrm{O}_{\mathrm{x}}$ losses were equal to approximately $20 \%$ of the gross $\mathrm{O}_{\mathrm{x}}$ production rate.

There are also several loss mechanisms for SOA. Evaporation of SOA is considered a loss mechanism in this framework of SOA production and loss, even though the loss may be temporary as the semivolatile species may condense later upon cooling or further reaction. Both primary and secondary species partition between the gas and condensed phases, depending on temperature, the total species concentration, and the concentration of the absorbing aerosol phase $\left(M_{\mathrm{o}}\right)$ (Pankow, 1994a, b). Depositional processes (wet or dry deposition) dominate the more permanent sinks of atmospheric fine PM. Wet deposition lifetimes are typically on the order of several days to a week, while lifetimes against dry 
deposition are typically longer (Dzepina et al., 2009; Nemitz et al., 2008). Values of at least a week seem reasonable for March 2006 in Mexico City given the general absence of precipitation until 23 March 2006 (the data from C-130 RF12 was likely affected by precipitation). Wet deposition also likely affected SOA concentrations in La Porte. Dry deposition of the gas-phase semivolatile oxygenated species that are in equilibrium with SOA is expected to be much faster, but it has not been constrained experimentally. If the deposition velocity of these oxygenated semivolatile organic compounds is as large as that of nitric acid, they would experience dry deposition losses of several percent per hour (Dzepina et al., 2009). The lack of quantitative characterization of these vapor losses adds uncertainty to any studies of SOA over longer time periods. Heterogeneous oxidation might also affect the lifetimes of organic aerosol, but the effect on the data presented here is probably not dramatic: laboratory results suggest such processes also require at least several days (Molina et al., 2004) though they may be important over substantially longer timescales (e.g., George et al., 2007). Field measurements also suggest that heterogeneous oxidation is of minor importance over the timescales studied here (Murphy et al., 2007; DeCarlo et al., 2008). The importance of SOA evaporation is examined in Sect. 4.5.

\subsection{Calculations of $P(\mathrm{SOA}) / P\left(\mathrm{O}_{\mathrm{x}}\right)$ with VOC measurements}

Using Eq. (4), $P(\mathrm{SOA}) / P\left(\mathrm{O}_{\mathrm{x}}\right)$ was calculated for each time period at PTP, T0, and La Porte with VOC canister measurements. The values used for the parameters $k_{\mathrm{OH}}, a$ and $F$ in the denominator of Eq. (4) are adopted from Rosen et al. (2004). $F$ is equivalent to the term $(1-\alpha)$ used by Rosen et al. (2004) where $\alpha$ is the yield for alkyl nitrate formation. For VOCs not listed in Rosen et al. (2004), literature values (Atkinson, 1994) were used when available and estimates made otherwise (see supporting information, Table S1). These estimates have a minor effect on the overall calculated values of $P(\mathrm{SOA}) / P\left(\mathrm{O}_{\mathrm{x}}\right)$ for the Mexico City and La Porte measurements; doubling or halving the estimates for $a$ and $k_{\mathrm{OH}}$ changes the calculated ratios by less than $10 \%$. We note that the VOCs that account for over $80 \%$ of calculated $P\left(\mathrm{O}_{\mathrm{x}}\right)$ have $a, k_{\mathrm{OH}}$, and $F$ values available in the literature. Similarly, varying the estimates of $F$ between 0.7 and 1 has a small $(<10 \%)$ impact on the final calculations. Peroxyacetyl nitrate (PAN, and other peroxyacyl compounds) are assumed to be in equilibrium with $\mathrm{NO}_{2}$ and their precursor peroxy acyl radicals (acetaldehyde for PAN). Net formation of peroxyacyl nitrates would require lowering the $F$ value for the corresponding OVOCs. Lowering the $F$ values for acetaldehyde and acetone (to account for net formation of peroxyacetyl nitrates) to 0.8 leads to calculated values of $P(\mathrm{OOA}) / P\left(\mathrm{O}_{\mathrm{x}}\right)$ that are at most $10 \%$ higher than the base case calculations.
Aerosol yields are based on the laboratory measurements of Odum et al (1997) and $\mathrm{Ng}$ et al. (2007b) for aromatic VOCs, Lim and Ziemann (2005) for alkanes, Carlton et al. (2009) for isoprene, and Griffin et al. (1999) for all other biogenic VOCs. Semivolatile partitioning (loadingand temperature-dependent yields) is not treated explicitly; instead the yields for each half-hour average $P(\mathrm{SOA}) / P\left(\mathrm{O}_{\mathrm{x}}\right)$ calculation are based on the ambient temperature and mass concentration of the absorbing particle phase $\left(M_{\mathrm{o}}\right.$, set equal to $[\mathrm{OOA}])$ at the time of the VOC measurements. We note that the calculations of $P(\mathrm{SOA}) / P\left(\mathrm{O}_{\mathrm{x}}\right)$ described here use measurements of OOA itself, an "advantage" that a 3-D predictive model would not have. If a model tends to underpredict SOA, using the measured $M_{\mathrm{o}}$ rather than a model calculation of this quantity results in an upper limit of the calculated SOA (Dzepina et al., 2009). A second set of calculations was performed with $M_{\mathrm{o}}$ set constant to a value of $5 \mu \mathrm{g} / \mathrm{m}^{3}$ for comparison. The yields for benzene, toluene, and xylene isomers are from the "high- $\mathrm{NO}_{\mathrm{x}}$ " parameterization of $\mathrm{Ng}$ et al. (2007b). We assign the yields measured for m-xylene (Ng et al., 2007b) to o- and p-xylene as well. All other aromatic VOCs are treated by assigning each precursor as a "high-yield" or "low-yield" aromatic and using the corresponding SOA yield parameterization (Odum et al., 1997). Aromatics other than those explicitly studied by Odum et al. (1997) (including PAHs) are assumed to be "high-yield". SOA yields from alkanes (Lim and Ziemann, 2005) have not been measured as a function of $M_{\mathrm{o}}$, and instead have only been measured at very high loadings. The $M_{\mathrm{O}}$-dependence of those species was estimated using Eq. (7) based on the 2product parameterization of Odum et al. (1996), assuming stoichiometric coefficients $(\alpha)$ are constant for all alkanes and equilibrium partitioning coefficient $\left(K_{\mathrm{p}}\right)$ values increase by a factor of 3 for each carbon added (Pankow and Asher, 2008).

$$
\begin{aligned}
Y\left(C, M_{\mathrm{o}}\right) & =\frac{0.512}{1+\left(M_{\mathrm{o}} \cdot 8 \times 10^{-6} \cdot 3^{(C-8)}\right)^{-1}} \\
& +\frac{0.041}{1+\left(M_{\mathrm{o}} \cdot 4.5 \times 10^{-3} \cdot 3^{(C-8)}\right)^{-1}}
\end{aligned}
$$

where $C$ is the number of carbons for each alkane. This results in yields (for $\left[M_{\mathrm{o}}\right]=5 \mu \mathrm{g} / \mathrm{m}^{3}$ ) ranging from $\sim 1 \%$ for alkanes with 10 carbons to $\sim 55 \%$ for alkanes with 19 or more carbons. Yields from other hydrocarbons (e.g., alkenes, cycloalkanes, etc) were assumed to be the same as those of n-alkanes with the same carbon number. Long-chain oxygenated organics, which are present in diesel exhaust (Schauer et al., 1999), were also assumed to have similar SOA yields, but with $K_{\mathrm{p}}$ values higher by a factor of 10 (for aldehydes) to 1000 (for carboxylic acids), consistent with the effect of functional groups on vapor pressures (Pankow and Asher, 2008). 
SOA formation from the oxidation of VOCs by $\mathrm{O}_{3}$ and $\mathrm{NO}_{3}$ is disregarded in these calculations but can be included by substituting the relevant analogous quantities (e.g., $\mathrm{VOC}+\mathrm{O}_{3}$ rate constants, $\mathrm{O}_{3}$ concentrations, and SOA yields from ozonolysis reactions) in Eq. (3) (Atkinson, 1994; Griffin et al., 1999). The product of these three terms is only competitive with $\mathrm{OH}$ reaction for biogenic VOCs.

Figure 6 depicts the calculated values of $P(\mathrm{SOA}) / P\left(\mathrm{O}_{\mathrm{x}}\right)$ plotted versus time of day for both the Mexico City and La Porte data sets. Each small dot represents the calculation using the individual 30-min average VOC concentrations and the large squares are the averages within each hour. Two sets of calculations were performed for both datasets one with the aerosol yields calculated using a fixed value of $5 \mu \mathrm{g} / \mathrm{m}^{3}$ for $M_{\mathrm{o}}$ and one calculated using the observed (timevarying) OOA concentration, which varied from $0.1 \mu \mathrm{g} / \mathrm{m}^{3}$ to over $15 \mu \mathrm{g} / \mathrm{m}^{3}$. Additionally, the Mexico City calculations are done both with and without limonene. The Mexico City calculations are dominated by measurements at PTP, with only a few measurements at T0 (including the two measurements between 06:00 and 08:00). The calculated values of $P(\mathrm{SOA}) / P\left(\mathrm{O}_{\mathrm{x}}\right)$ range from 2 to $48 \mu \mathrm{g} \mathrm{m}^{-3} / \mathrm{ppmv}$ for the Mexico City measurements and 1 to 26 for the La Porte measurements. For both cases, the calculations are almost an order of magnitude lower than the observed values of $\Delta[\mathrm{OOA}] / \Delta\left[\mathrm{O}_{\mathrm{x}}\right]$ shown in Fig. 3.

For La Porte (with $M_{\mathrm{o}}$ set to $5 \mu \mathrm{g} / \mathrm{m}^{3}$ ), calculated $P(\mathrm{SOA}) / P\left(\mathrm{O}_{\mathrm{x}}\right)$ values are lowest during the day because aromatic VOCs account for the smallest fraction of total VOCs during the day. The calculated values of $P(\mathrm{SOA}) / P\left(\mathrm{O}_{\mathrm{x}}\right)$ are slightly higher at night (not shown) but are not very meaningful since the absolute values of $P(\mathrm{SOA})$ and $P\left(\mathrm{O}_{\mathrm{x}}\right)$ are both very low. The calculated diurnal trend for the Mexico City dataset (with $M_{\mathrm{o}}$ constant) is similar to the La Porte trend. Differences between the actual OOA concentrations and the fixed $M_{\mathrm{o}}$ value of $5 \mu \mathrm{g} / \mathrm{m}^{3}$ at times leads to substantial differences between the 2 sets of calculations in Mexico City and La Porte. In all cases, however, the calculated ratio of production rates are much smaller than the observed values of $\Delta \mathrm{OOA} / \Delta \mathrm{O}_{\mathrm{x}}$.

Although the calculations do not reproduce the observed values of $\triangle O O A / \Delta \mathrm{O}_{\mathrm{x}}$, an examination of the relative contribution of various VOC classes to these calculations provides insight into the discrepancy. We focus on the detailed results from two distinct time periods and locations: 1) early morning at $\mathrm{T} 0$ in Mexico City (close to fresh urban emissions), and 2) afternoon measurements on 30 August 2000 at La Porte during a well-studied photochemical episode. For each of the two cases, the contribution of each category of VOCs to both $P\left(\mathrm{O}_{\mathrm{x}}\right)$ and $P(\mathrm{SOA})$ along with the $P(\mathrm{SOA}) / P\left(\mathrm{O}_{\mathrm{x}}\right)$ ratio are shown in Fig. 7, with detailed information available in the supporting information (Tables S2 and S3). A value of $5 \mu \mathrm{g} / \mathrm{m}^{3}$ was used for $M_{\mathrm{o}}$ for these calculations shown in Fig. 7. The underestimation of $P\left(\mathrm{O}_{\mathrm{x}}\right)$ caused by ignoring the peroxy radicals produced directly from formaldehyde pho-

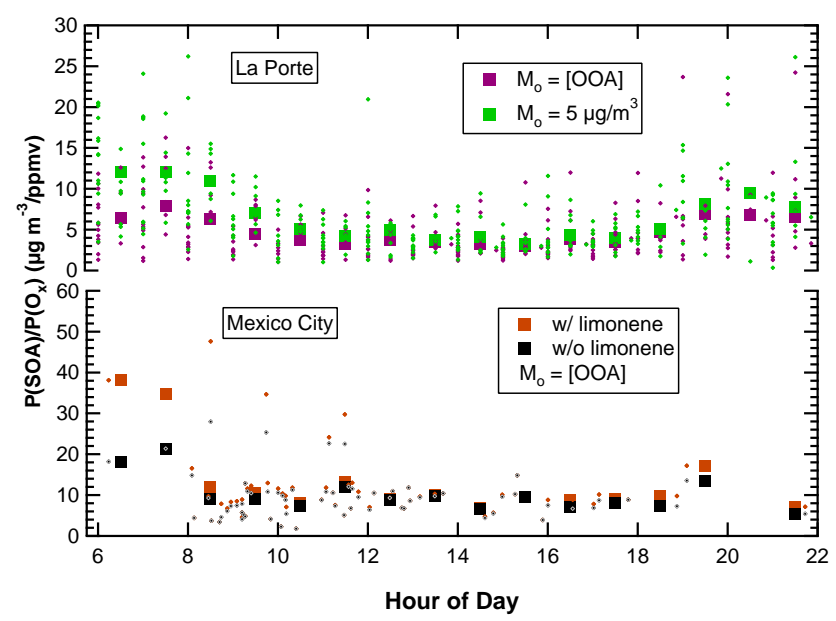

Fig. 6. Calculated $P(\mathrm{SOA}) / P\left(\mathrm{O}_{\mathrm{x}}\right)$ versus time of day in Mexico City and La Porte. Each small circle represents a calculation using the 30-min average VOC measurements, and the large squares are the averages of all measurements within an hour window of time. For La Porte, the $P(\mathrm{SOA}) / P\left(\mathrm{O}_{\mathrm{x}}\right)$ calculations shown were made with SOA yields based on both a fixed $M_{\mathrm{O}}$ value of $5 \mu \mathrm{g} / \mathrm{m}^{3}$ (green) and a dynamic $M_{\mathrm{O}}$ set equal to the ambient OOA concentration at the time of the VOC measurement (purple). The Mexico City calculations shown were made with and without the limonene measurements (with a dynamic $M_{\mathrm{o}}$ value in both cases).

tolysis is calculated as $15 \%$ at most. This simplification is needed so that the $\mathrm{OH}$ terms cancel in Eq. (4).

The morning measurements at T0 in Mexico City (Fig. 7) were made between 06:00 and 06:30 on 29 March 2006, during a low biomass burning period (Aiken et al., 2010). They are assumed to be representative of typical urban emissions in Mexico City (similar to those presented by Velasco et al., 2007). VOCs during this time period had experienced minimal photochemical processing. The PTR-MS measurements of total C2-benzenes were assumed to consist of $17 \%$ ethyl benzenes and the remainder xylene isomers, in agreement with the speciation measured by Velasco et al. (2007) and that observed in a Mexican road tunnel (Mugica, 2001). PTR-MS measurements of C3-benzenes were assumed to consist of 7\% propyl-benzenes (Rogers et al., 2006), 48\% trimethylbenzenes, and $45 \%$ ethyltoluene isomers. $P(\mathrm{SOA}) / P\left(\mathrm{O}_{\mathrm{x}}\right)$ was calculated twice: once with all measured VOCs, and once with limonene disregarded. Limonene, which reacts rapidly with $\mathrm{OH}$ and has a high SOA yield, was reported at a seemingly high concentration of $2.6 \mathrm{ppb}$. It is not clear if the limonene observed was of biogenic origin (in which case the concentrations were likely well mixed spatially) or of anthropogenic origin (e.g., due to nearby cleaning activity), in which case the measurements may not reflect the overall VOC composition of Mexico City. Isoprene and $\alpha$-pinene concentrations, two other compounds of predominantly biogenic origin, were $0.33 \mathrm{ppbv}$ and $2.6 \mathrm{ppbv}$, respectively, suggesting that there may have 


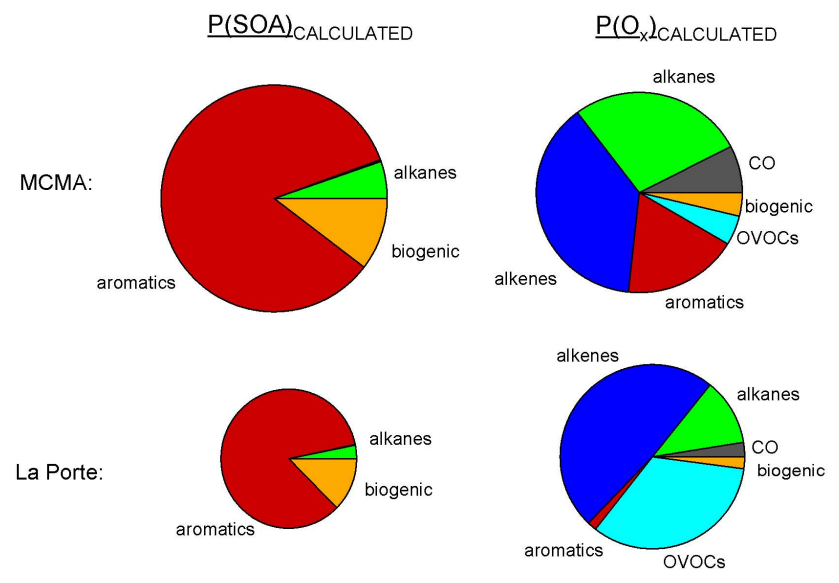

Fig. 7. Relative contributions of precursors to $\mathrm{SOA}$ and $\mathrm{O}_{\mathrm{x}}$ production calculated using VOC measurements at $\mathrm{T} 0$ in Mexico City at 06:30, 29 March 2006 and at La Porte at 14:00, 31 August 2000. Pie charts are not shown to scale (i.e., since absolute $P\left(\mathrm{O}_{\mathrm{x}}\right)$ and $P(\mathrm{SOA})$ rates depend on $[\mathrm{OH}]$, the sizes of the La Porte and Mexico City pie charts should not be compared quantitatively).

been a non-negligible biogenic influence on the air mass. For comparison, the $24 \mathrm{~h}$ average isoprene mixing ratio at $\mathrm{T} 0$ during the entire month was $0.213 \pm 0.134 \mathrm{ppb}$ ( 1 sigma) (Apel et al., 2010), indicating that the measurements on 29 March are not extraordinary. Nevertheless, both simulations (with and without limonene) are considered because of the large impact limonene has on the results.

The $P(\mathrm{SOA}) / P\left(\mathrm{O}_{\mathrm{x}}\right)$ ratio using VOC measurements obtained between 08:00 and 11:00 at PTP is $32 \mu \mathrm{g} \mathrm{m}^{-3} / \mathrm{ppmv}$ calculated with all VOCs and $19 \mu \mathrm{g} \mathrm{m}^{-3} / \mathrm{ppmv}$ with limonene disregarded. These calculated values are factors of 5 and 8 lower than the measured value of 160 for $\Delta[\mathrm{OOA}] / \Delta\left[\mathrm{O}_{\mathrm{x}}\right]$. The largest contributors to $P\left(\mathrm{O}_{\mathrm{x}}\right)$ are alkenes and aromatic VOCs, accounting for a combined $62 \%$ of $P\left(\mathrm{O}_{\mathrm{x}}\right)$, with the remainder almost evenly split between alkanes, $\mathrm{CO}$, and oxygenated VOCs (OVOC). The relative contribution of these VOC groups to ozone formation was similar to those reported by Lei et al. (2007).

With limonene disregarded, aromatic VOCs account for $84 \%$ of the calculated $P(\mathrm{SOA})$, consistent with previous results in Mexico City using traditional SOA models (Dzepina et al., 2009; Volkamer et al., 2006). The only non-aromatic compounds that account for at least $1 \%$ of $P(\mathrm{SOA})$ are a-pinene, n-undecane, and n-dodecane, which account for $10 \%, 1.7 \%$, and $1.7 \%$ of $P(\mathrm{SOA})$, respectively. When included, limonene accounts for $10 \%$ of $P\left(\mathrm{O}_{\mathrm{x}}\right)$ and almost $50 \%$ of $P(\mathrm{SOA})$. The calculation summarized in Fig. 7 uses a fixed $M_{\mathrm{O}}$ value of 5 to facilitate comparison to the La Porte data set. $M_{\mathrm{O}}$ was set equal to the observed OOA concentration for the simulations presented in Fig. 6. $\left[\mathrm{O}_{3}\right]$ was near zero due to the high NO concentration, and we can deduce that $\left[\mathrm{NO}_{3}\right]$ was near zero as well. Thus SOA formation from reactions of organic compounds with $\mathrm{O}_{3}$ and $\mathrm{NO}_{3}$ was negligible.

The high $\mathrm{O}_{3}$ episode on 31 August 2000 in La Porte, Texas has been well characterized in the literature (Jobson et al., 2004) and serves as a good contrast to the urban VOC mix in Mexico City. The high ozone concentrations (>200 ppbv) observed were largely caused by very high concentrations of light alkenes (mainly ethene and propene) emitted by petrochemical facilities. Since these compounds and their oxidation products have high vapor pressures, they are not expected to contribute greatly to SOA formation (though we note that oxidation of ethyne can lead to SOA formation via glyoxal uptake, Volkamer et al., 2009). The much lower slope of $\Delta[\mathrm{OOA}] / \Delta\left[\mathrm{O}_{\mathrm{x}}\right]$ observed during the petrochemical plume confirms that oxidation of small alkenes does not produce appreciable amounts of SOA. Almost $50 \%$ of the calculated $\mathrm{O}_{\mathrm{x}}$ production is due to ethene and propene, with the remainder due to oxygenated VOCs $(33 \%)$ and alkanes $(12 \%)$. Aromatic VOCs are minor contributors to $P\left(\mathrm{O}_{\mathrm{x}}\right)$ in La Porte (less than 2\%), though they account for over $20 \%$ of $P\left(\mathrm{O}_{\mathrm{x}}\right)$ at $\mathrm{T} 0$ in Mexico City. The calculated contributions to SOA production in La Porte are similar to those in Mexico City: over 80\% from aromatic VOCs, 3\% from large (>C9) alkanes, and $12 \%$ from the sum of isoprene, $\alpha$-pinene, and limonene. The calculated $P(\mathrm{SOA}) / P\left(\mathrm{O}_{\mathrm{x}}\right)$ ratio is $1.9 \mu \mathrm{g} \mathrm{m}^{-3} / \mathrm{ppmv}$, compared to the observed value of $30 \mu \mathrm{g} \mathrm{m}^{-3} / \mathrm{ppmv}$ on 30 August 2000 (in the industrial plume). The explanation for the smaller calculated value of $P(\mathrm{SOA}) / P\left(\mathrm{O}_{\mathrm{x}}\right)$ in La Porte is that aromatic VOCs account for a smaller portion of total VOCs, and a large portion of $P\left(\mathrm{O}_{\mathrm{x}}\right)$ is from light alkenes, which do not form significant SOA. The discrepancy factor of 12 between the calculated values of $P(\mathrm{SOA}) / P\left(\mathrm{O}_{\mathrm{x}}\right)$ and the measured $\Delta[\mathrm{OOA}] / \Delta\left[\mathrm{O}_{\mathrm{x}}\right]$ is larger than that for the T0 calculation. This is partially explained by the fact that the two measured VOC datasets are not identical (e.g., n-undecane and n-dodecane were not measured in La Porte). Limonene accounts for on average $10 \%$ to $15 \%$ of calculated $P(\mathrm{SOA})$ in La Porte, even with an average mixing ratio of only 9 ppt. Ozonolysis was not included in the calculations depicted in Fig. 7. We calculate that the contributions to SOA formation from ozonolysis of isoprene, $\alpha$-pinene, and limonene are comparable to that from $\mathrm{OH}$ reaction.

\subsection{The discrepancy between models and measurements}

We estimate that the uncertainty in $P(\mathrm{SOA}) / P\left(\mathrm{O}_{\mathrm{x}}\right)$ calculated using Eq. (4) is at most a factor of three, and dominated by the uncertainty in the SOA yields. These calculated values of $P(\mathrm{SOA}) / P\left(\mathrm{O}_{\mathrm{x}}\right)$ are 5 to 15 times lower than the observed $[\mathrm{OOA}] /\left[\mathrm{O}_{\mathrm{x}}\right]$ values. This range of "discrepancy factors" is similar to those found in several prior studies. Calculations of SOA off the coast of New England by de Gouw et al. (2005) using measurements of gas-phase precursors and 
particulate organic matter (and older, lower SOA yields for aromatic VOCs) were low by a factor of 14 . Calculations of [SOA] in Mexico City in 2003 using an SOA partitioning model constrained by measurements of $\mathrm{OH}$, VOCs, and other species at a more urban site in Mexico City were also low by at least a factor of 8 (Volkamer et al., 2006), although a reanalysis of that case study with more realistic assumptions concluded that the underestimate with traditional models was a factor of 17 (Dzepina et al., 2009). In both those studies, aromatic VOCs were calculated to be the most important SOA precursors, accounting for $79 \%$ (deGouw) and $80 \%$ (Volkamer) of SOA formation, whereas alkanes contributed 21\% (deGouw) and 4\% (Volkamer), and alkenes $0 \%$ (deGouw) and 16\% (Volkamer). The magnitude of the models' underestimations cannot be solely attributed to uncertainty in the SOA yields. Although these yields are a function of several parameters such as $\left[\mathrm{NO}_{\mathrm{x}}\right]$ and existing gas-phase and aerosol concentrations, and though synergistic interactions between various compounds may not be captured in laboratory studies, increases by a factor of 10 are unlikely. Dzepina et al (2009) evaluated the effect of the low- $\mathrm{NO}_{\mathrm{x}}$, high yield channels for SOA formation from aromatic VOCs (Ng et al., 2007b) in Mexico City and concluded that it has a negligible effect $(<1 \%)$ on the high- $\mathrm{NO}_{\mathrm{x}}$ environment of downtown Mexico City.

Use of the net rather than the gross $\mathrm{O}_{\mathrm{x}}$ and SOA calculated production rates would lead to more accurate predictions of $\Delta[\mathrm{OOA}] / \Delta\left[\mathrm{O}_{\mathrm{x}}\right]$, though it is unlikely that $\mathrm{O}_{\mathrm{x}}$ and SOA losses can account for the order of magnitude shortfall between the calculations and the observations. For example, during the afternoon of 12 March 2006 at PTP, the gross production rate of $\mathrm{O}_{\mathrm{x}}$ was $50 \mathrm{ppbv} / \mathrm{hr}$ and the $\mathrm{O}_{\mathrm{x}}$ destruction rate was $12 \mathrm{ppbv} / \mathrm{hr}$ (Wood et al., 2009). If this ratio of $\mathrm{O}_{\mathrm{x}}$ destruction to production rates always held true (a generalization) and the SOA loss rates were negligible compared to the production rates, then this would decrease the discrepancy by only $20 \%$.

The SOA yields used in the $P(\mathrm{SOA}) / P\left(\mathrm{O}_{\mathrm{x}}\right)$ calculations were based on $M_{\mathrm{O}}$ values set equal to either $5 \mu \mathrm{g} / \mathrm{m}^{3}$ or the observed OOA concentration - the latter choice based on the results of Song et al. (2007). If total organic aerosol (including POA) is actually a more appropriate proxy for $M_{\mathrm{O}}$ and were used to calculate the SOA yields, the calculated values of $P(\mathrm{SOA}) / P\left(\mathrm{O}_{\mathrm{x}}\right)$ would increase and be closer to the observed $\Delta[\mathrm{OOA}] / \Delta\left[\mathrm{O}_{\mathrm{x}}\right]$ values. For example, increasing $M_{\mathrm{O}}$ from $5 \mu \mathrm{g} / \mathrm{m}^{3}$ to $20 \mu \mathrm{g} / \mathrm{m}^{3}$ increases the high- $\mathrm{NO}_{\mathrm{x}}$ SOA yield for toluene by $75 \%$ ( $\mathrm{Ng}$ et al., 2007b).

The results of Hofzumahaus et al. (2009) suggest that Eq. (2) may overestimate the true values of $P\left(\mathrm{O}_{\mathrm{x}}\right)$. An overestimation of $P\left(\mathrm{O}_{\mathrm{x}}\right)$ would lead to an underestimation of $P(\mathrm{SOA}) / P\left(\mathrm{O}_{\mathrm{x}}\right)$ and be consistent with the discrepancy between the calculated values of $P(\mathrm{SOA}) / P\left(\mathrm{O}_{\mathrm{x}}\right)$ and the observed values of $\Delta[\mathrm{OOA}] / \Delta\left[\mathrm{O}_{\mathrm{X}}\right]$. In order to assess the accuracy of the $P\left(\mathrm{O}_{\mathrm{x}}\right)$ calculations using Eq. (2), we compare the calculated values of $P\left(\mathrm{O}_{\mathrm{x}}\right)$ to those determined for both
Mexico City and La Porte by other methods. For calculations of daytime $P\left(\mathrm{O}_{\mathrm{x}}\right)$ (between 11:00 and 15:00 local time), a value of $6 \times 10^{6}$ molecules $/ \mathrm{cm}^{3}$ is assumed for $[\mathrm{OH}]$, based on $\mathrm{OH}$ measurements near the center of Mexico City from 2003 (Shirley et al., 2006) and 2006 (Dusanter et al., 2009) and a model estimate from the afternoon of 12 March at PTP (Wood et al., 2009). Such estimates of $[\mathrm{OH}]$ are only needed to calculate the absolute values of $P\left(\mathrm{O}_{\mathrm{x}}\right)$ and are not used to calculate $P(\mathrm{SOA}) / P\left(\mathrm{O}_{\mathrm{x}}\right)$. Calculated values of $P\left(\mathrm{O}_{\mathrm{x}}\right)$ using these assumed $[\mathrm{OH}]$ values between 11:00 and 15:00 at PTP range from 15 to $67 \mathrm{ppbv} / \mathrm{hr}$, consistent with the value of $50 \mathrm{ppbv} / \mathrm{hr}$ observed on the afternoon of 12 March 2006 (Wood et al., 2009). $P\left(\mathrm{O}_{\mathrm{x}}\right)$ calculated using VOC measurements at T0 between 08:30 and 10:00 on 29 March are 110 to $120 \mathrm{ppbv} / \mathrm{hr}$ (using $[\mathrm{OH}]=4 \times 10^{6}$ molecules $/ \mathrm{cm}^{3}$ ). For comparison, the portion of $P\left(\mathrm{O}_{\mathrm{x}}\right)$ that is due to the reaction of $\mathrm{HO}_{2}$ and $\mathrm{NO}$ only (i.e., excluding the oxidation of NO by organic peroxy radicals) has been calculated as $80 \mathrm{ppbv} / \mathrm{hr}$ between 08:00 and 10:00 based on measurements of $\mathrm{HO}_{2}$ and $\mathrm{NO}$ at T0 (Dusanter et al., 2009). $P\left(\mathrm{O}_{\mathrm{x}}\right)$ calculated for 14:00 at La Porte on 30 August 2000 (in a highly reactive petrochemical plume) is $38 \mathrm{ppbv} / \mathrm{hr}$ (also using $[\mathrm{OH}]=6 \times 10^{6}$ molecules $/ \mathrm{cm}^{3}$ ), whereas the interquartile of $P\left(\mathrm{O}_{\mathrm{x}}\right)$ values for petrochemical plumes calculated in Kleinman et al. (2005) is 30 to $70 \mathrm{ppbv} / \mathrm{hr}$. The generally good agreement in $P\left(\mathrm{O}_{\mathrm{x}}\right)$ calculated using Eq. (2) and the other methods suggests that our $P\left(\mathrm{O}_{\mathrm{x}}\right)$ calculations are not greatly overestimated.

This model used here only considers gas-phase species (VOCs) as OOA precursors. Oxidation of primary organic aerosol (heterogenously or in the gas-phase following evaporation) is another source of OOA that this framework of $P(\mathrm{SOA}) / P\left(\mathrm{O}_{\mathrm{x}}\right)$ does not include, though likely a minor one (Zhang et al., 2007).

\section{4 $P(\mathrm{SOA}) / P\left(\mathrm{O}_{\mathrm{x}}\right)$ for gasoline and diesel exhaust}

The accuracy of the $P(\mathrm{SOA}) / P\left(\mathrm{O}_{\mathrm{x}}\right)$ calculations using Eq. (4) relies on the completeness of the VOC datasets. Although an extensive number of VOCs were measured in both Mexico City and La Porte, numerous organic compounds that are emitted from on-road vehicles (and other emission sources) were not measured. These compounds likely play an important role in SOA formation and possibly ozone formation as well. Measurements of the total $\mathrm{OH}$ reactivity (Kovacs and Brune, 2001) in several urban settings including Mexico City (Shirley et al., 2006) and New York (Ren et al., 2003) have been shown to agree with the total $\mathrm{OH}$ reactivity calculated using measured VOC concentrations and known literature values for $\mathrm{OH}$ rate constants $\left(\Sigma k_{\mathrm{OH}+\mathrm{VOC}}[\mathrm{VOC}]\right)$ only to within $30 \%$. Sheehy et al. (2008) report that the measured $\mathrm{OH}$ reactivity in Mexico City is underpredicted from that calculated using VOC measurements, especially during the morning rush hour. A similar gap was observed between the measured total $\mathrm{C}-\mathrm{H}$ stretches using Fourier transform 
infrared spectroscopy during MCMA-2003 and those calculated from the measured species (Dzepina et al., 2009). Measurements of total non-methane organic carbon mass (Chung, 2003; Lewis, 2000) exceeded the sum of speciated VOCs by up to $20-45 \%$ in photochemically aged air in southern California and Melbourne, thus indicating the existence of "missing" VOCs.

To assess the importance of unmeasured VOCs, we calculate the relative rates of $P(\mathrm{SOA})$ and $P\left(\mathrm{O}_{\mathrm{x}}\right)$ using the emission factors for gasoline (petrol)- and diesel-fueled vehicles from Schauer et al. (1999, 2002). These studies quantified over 140 VOCs in both the gas and particulate phases in the exhaust of diesel vehicles, gasoline vehicles with a catalytic converter, and gasoline vehicles without a catalytic converter. The emission factors of these studies (in $\mu \mathrm{g}$ of VOC per $\mathrm{km}$ driven) were converted to molar emission rates and used in Eq. (4). Absolute rates of $P(\mathrm{SOA})$ and $P\left(\mathrm{O}_{\mathrm{x}}\right)$ are not calculated since that would require extrapolation of the emission rates to ambient concentrations and an estimate of the $\mathrm{OH}$ concentration. The ratio of $P(\mathrm{SOA})$ to $P\left(\mathrm{O}_{\mathrm{x}}\right)$, however, depends only on the relative VOC speciation and the value of $M_{\mathrm{o}}$ used to calculate SOA yields ( $5 \mu \mathrm{g} / \mathrm{m}^{3}$ for these calculations).

A large portion of the organic carbon emitted by diesel engines could not be resolved as discrete peaks in gas chromatographs (Schauer et al., 1999, 2002). These emissions are known as the "unresolved complex mixture" and henceforth referred to as "UCM". The total mass of the semivolatile gas-phase UCM was equal to $19 \%$ of the total volatile emissions and $123 \%$ of the total mass of particulate matter in diesel exhaust (measured at an exhaust dilution ratio of 130). The total mass of the particulate UCM was equal to $95 \%$ of the total particulate matter emissions. The mass of gaseous UCM measured from gasoline vehicles accounted for less than $1 \%$ of total emissions (Schauer et al., 2002). Particulate matter emissions from gasoline-fueled vehicles were negligible - equal to less than $1 \%$ of total VOC emissions by mass.

Calculations of $P(\mathrm{SOA})$ and $P\left(\mathrm{O}_{\mathrm{x}}\right)$ for both gasoline and diesel engines using the tabulated VOC emission factors of Schauer et al. $(1999,2002)$ are summarized in Fig. 8 and Table 1. CO emissions were not quantified by Schauer et al. $(1999,2002)$. CO emission factors of $14 \mathrm{~g} / \mathrm{km}$ and $5.5 \mathrm{~g} / \mathrm{km}$ were used for gasoline and diesel vehicles, respectively, based on fuel-based emission factors reported elsewhere (Ban-Weiss et al., 2008; Zavala et al., 2009) and assumed fuel efficiencies of $6.6 \mathrm{~km} / \mathrm{L}$ for gasoline vehicles and $1.4 \mathrm{~km} / \mathrm{L}$ for diesel vehicles. The emission rate of methyl tertiary butyl ether (MTBE) was set to zero for the calculations.

The calculation of $P\left(\mathrm{O}_{\mathrm{x}}\right)$ for gasoline engines is similar to that calculated using ambient VOC measurements. Total alkanes, alkenes, aromatic VOCs, oxygenated VOCs, and CO account for $20 \%, 39 \%, 24 \%, 10 \%$, and $7 \%$ of $P\left(\mathrm{O}_{\mathrm{x}}\right)$ in gasoline exhaust, respectively. This calculation assumes that $20 \%$ of the on-road vehicles do not have functioning
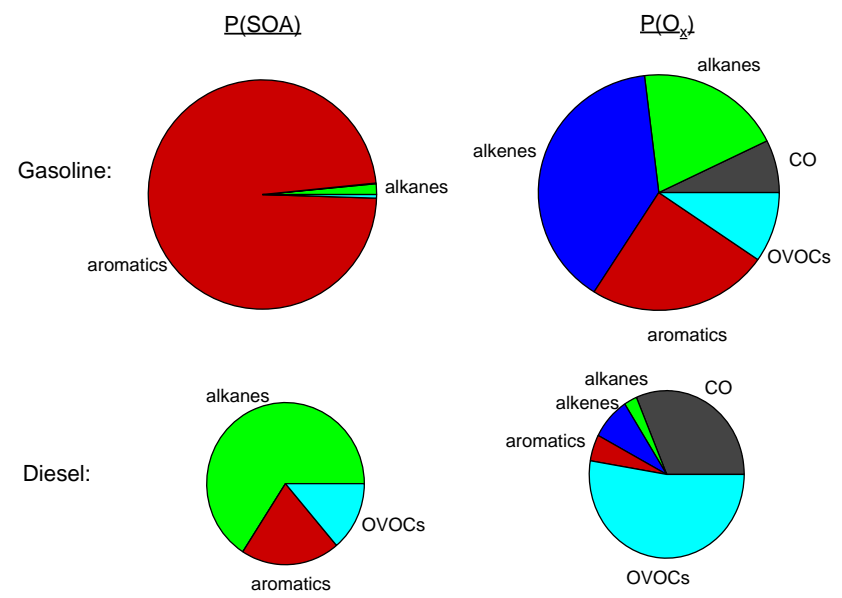

Fig. 8. Relative contributions of VOC classes to SOA and $\mathrm{O}_{\mathrm{x}}$ production calculated using VOC emission factors for gasoline and diesel-fueled vehicles and Eqs. (2) and (3) ("gaseous only, no UCM" case). Pie charts not shown to scale.

catalytic converters, as is the case in Mexico City (Zavala et al., 2009). VOC emissions from gasoline engines without a standard 3-way catalytic converter are roughly an order of magnitude higher than those with catalysts (Schauer et al., 2002), though there is some variation among the VOCs. Compounds that were measured in Mexico City and La Porte (i.e., VOCs with carbon number between 2 and 12) account for over $90 \%$ of $P\left(\mathrm{O}_{\mathrm{x}}\right)$ from gasoline-fueled vehicles. Of the total calculated $P(\mathrm{SOA})_{\mathrm{GASOLINE}}, 97 \%$ is accounted for by aromatic VOCs. These calculations for gasoline exhaust roughly agree with laboratory studies of gasoline photo-oxidation, in which the aromatic fraction of the fuel was found to account for $85 \%$ to $100 \%$ of the SOA produced upon oxidation (Kleindienst et al., 2002; Odum et al., 1997). The calculated ratio $P(\mathrm{SOA}) / P\left(\mathrm{O}_{\mathrm{x}}\right)$ for gasoline exhaust is $18.7 \mu \mathrm{g} \mathrm{m}^{-3} / \mathrm{ppm}$ - slightly higher than the ratio calculated using available VOC measurements and still much lower than the observed values for $\Delta[\mathrm{OOA}] / \Delta\left[\mathrm{O}_{\mathrm{x}}\right]$ (80 to 160) in Mexico City.

Four sets of calculations are performed for diesel exhaust and are summarized in Table 2. The first case ("gaseous only") considers only the gas-phase emissions from Schauer et al. (1999) and ignores the UCM emissions and all PM emissions. The second case ("gaseous + UCM") includes the gaseous UCM emissions. The third case ("gaseous + PM") includes both the gaseous and particulate emissions, with the hypothetical assumption that all particulate matter emissions evaporate upon dilution. The fourth case ("gaseous/PM + UCM") also includes the particulate UCM emissions. This case serves as an upper bound for the SOA that could be produced from the evaporation and subsequent oxidation of the semi-volatile components of the exhaust. The calculations for the "gaseous only" case indicate that alkanes and alkenes only account for 3\% and $8 \%$ of 
Table 1. Summary of the relative contribution of various VOC classes to $\mathrm{O}_{\mathrm{x}}$ and SOA production from gasoline and diesel exhaust. The on-road fuel mix is defined as $22 \%$ diesel and $78 \%$ gasoline by volume. The "benzene + C2, C3 benzenes" category includes benzene, toluene, ethyl benzene, xylenes, propyl benzenes, trimethyl benzenes, and ethyl toluenes. SOA yields are based on an $M_{\mathrm{O}}$ value of $5 \mu \mathrm{g} / \mathrm{m}^{3}$. UCM not included.

\begin{tabular}{|c|c|c|c|c|c|c|}
\hline & \multicolumn{2}{|c|}{ Gasoline } & \multicolumn{2}{|c|}{ Diesel } & \multicolumn{2}{|c|}{ On-road mix } \\
\hline & $P\left(\mathrm{O}_{\mathrm{x}}\right) \%$ & $P(\mathrm{SOA}) \%$ & $P\left(\mathrm{O}_{\mathrm{x}}\right) \%$ & $P(\mathrm{SOA}) \%$ & $P\left(\mathrm{O}_{\mathrm{x}}\right) \%$ & $P(\mathrm{SOA}) \%$ \\
\hline $\mathrm{CO}$ & 7.2 & 0 & 29.9 & 0 & 7.6 & 0 \\
\hline Alkanes & 19.6 & 2.0 & 2.5 & 67.5 & 19.2 & 4.4 \\
\hline $\mathrm{C} 2-\mathrm{C} 12$ alkanes & 19.6 & 1.6 & 2.0 & 29.0 & 19.2 & 2.6 \\
\hline$>\mathrm{C} 12$ alkanes & 0 & 0.4 & 0.5 & 38.5 & 0 & 2.8 \\
\hline Alkenes & 38.8 & 0.1 & 7.8 & 0 & 38.0 & 0.0 \\
\hline C2-C5 alkenes & 38.8 & 0.1 & 7.8 & 0 & 38.0 & 0.0 \\
\hline$>\mathrm{C} 5$ alkenes & 0 & 0.0 & 0 & 0 & 0 & 0 \\
\hline Aromatics & 24.3 & 97.0 & 4.8 & 14.1 & 23.8 & 93.9 \\
\hline benzene $+\mathrm{C} 2, \mathrm{C} 3$ benzenes & 17.3 & 83.3 & 1.5 & 4.3 & 20.3 & 80.3 \\
\hline other aromatics & 3.0 & 13.7 & 3.3 & 9.8 & 3.5 & 13.6 \\
\hline OVOC & 9.6 & 1.0 & 50.1 & 18.4 & 10.6 & 1.6 \\
\hline $\mathrm{HCHO}, \mathrm{CH}_{3} \mathrm{CHO}, \mathrm{CH}_{3} \mathrm{COCH}_{3}$ & 7.1 & 0 & 32.3 & 0 & 7.7 & 0 \\
\hline other OVOCs & 2.5 & 1.0 & 17.8 & 18.4 & 2.9 & 1.6 \\
\hline$P(\mathrm{SOA}) / P\left(\mathrm{O}_{\mathrm{x}}\right)\left(\mathrm{ug} \mathrm{m}^{-3} / \mathrm{ppmv}\right)$ & 18.7 & & 28 & & 19.0 & \\
\hline
\end{tabular}

Table 2. Summary of $P(\mathrm{SOA}) / P\left(\mathrm{O}_{\mathrm{x}}\right)$ calculations for diesel and gasoline exhaust.

\begin{tabular}{ll}
\hline Case & $\begin{array}{l}P(\mathrm{SOA}) / P\left(\mathrm{O}_{\mathrm{x}}\right) \\
\mu \mathrm{g} \mathrm{m}^{-3} / \mathrm{ppm}\end{array}$ \\
\hline gasoline (20\% w/o catalyst) & 18.7 \\
diesel (gaseous only, no UCM) & 28 \\
diesel (gaseous only, with UCM) & 232 \\
diesel (gaseous + PM, no UCM) & 31 \\
diesel (gaseous + PM, with UCM) & 380 \\
urban mix (22\% diesel, 78\% gasoline, gaseous only) & 19.0 \\
urban mix (gaseous+PM, with UCM) & 34 \\
Mexico City $\Delta[\mathrm{OOA}] / \Delta\left[\mathrm{O}_{\mathrm{x}}\right]$ & 100 to 160 \\
La Porte $\Delta[\mathrm{OOA}] / \Delta\left[\mathrm{O}_{\mathrm{x}}\right]$ & 30 to 120 \\
\hline
\end{tabular}

$P\left(\mathrm{O}_{\mathrm{x}}\right)$ in diesel exhaust, respectively, whereas $\mathrm{CO}$ accounts for $30 \%$ and OVOCs account for $50 \%$ (largely from acetaldehyde and propanal). Alkanes, OVOCs, and aromatic VOCs account for $68 \%, 18 \%$, and $14 \%$ of calculated $P(\mathrm{SOA})$ from diesel exhaust - a stark contrast from that calculated for gasoline exhaust. The calculated ratio $P(\mathrm{SOA}) / P\left(\mathrm{O}_{\mathrm{x}}\right)$ for diesel exhaust (the "gaseous only" case) is 28 . The large contribution of alkanes to calculated $P(\mathrm{SOA})$ in diesel exhaust is due to the high yields of large alkanes as discussed earlier.

For the "gaseous + UCM" case, the UCM is treated as a compound with an SOA yield of $50 \%$, an $\mathrm{OH}$ rate constant of $3 \times 10^{-11} \mathrm{~cm}^{3}$ molecule $\mathrm{s}^{-1}$, an $F$ value of 0.7 and an $a$ value of 2 . The calculated value of $P(\mathrm{SOA}) / P\left(\mathrm{O}_{\mathrm{x}}\right)$ for this "gaseous + UCM" case is 232 , with the UCM accounting for $88 \%$ of $P(\mathrm{SOA})$. This is in semi-quantitative agreement with diesel oxidation experiments which have shown that aromatic VOCs are minor SOA precursors in diesel exhaust (Weitkamp et al., 2007). The calculated values of $P(\mathrm{SOA}) / P\left(\mathrm{O}_{\mathrm{x}}\right)$ for diesel exhaust are 31 when the resolved particulate emissions are included (but ignoring UCM) and 340 when all gaseous, particulate, and UCM emissions are included. Calculated $P\left(\mathrm{O}_{\mathrm{x}}\right)$ is minimally affected by UCM because of its relatively low molar emission rate.

The final two columns in Table 1 are calculations of $P(\mathrm{SOA}) / P\left(\mathrm{O}_{\mathrm{x}}\right)$ for an "urban mix" consisting of $78 \%$ gasoline and $22 \%$ diesel by volume according to their proportional fuel sales in Mexico City and assuming that the fuel efficiency $(\mathrm{km} / \mathrm{L})$ of gasoline-fueled vehicles was five times that of diesel-fueled vehicles (a necessary assumption since the emission factors from Schauer et al. $(1999,2002)$ are distance-based rather than fuel-based). With only the gaseous emissions (no UCM) considered for diesel exhaust, the calculated value of $P(\mathrm{SOA}) / P\left(\mathrm{O}_{\mathrm{x}}\right)$ for the urban mix is 19 - only slightly higher than that calculated for gasoline vehicles only. When (gaseous) UCM emissions are included, $P(\mathrm{SOA}) / P\left(\mathrm{O}_{\mathrm{x}}\right)$ only increases to 28 (34 if particulate $\mathrm{UCM}$ is included). These calculations (incorrectly) indicate that both $P\left(\mathrm{O}_{\mathrm{x}}\right)$ and $P(\mathrm{SOA})$ are dominated by gasoline emissions due to the high absolute emission rates of alkenes and aromatic VOCs compared to diesel vehicles. This "urban mix" is not meant as a true representation of the Mexico City 
urban fleet, since it does not account for CNG or LNG-fueled vehicles nor any non-road emission sources. Additionally, there are differences between the VOC emission profiles used for the calculations (based on California vehicles from the 1990s) (Schauer et al., 1999, 2002) and those observed in a tunnel in Mexico City (Mugica, 2001). Note that the calculated value of $P(\mathrm{SOA}) / P\left(\mathrm{O}_{\mathrm{x}}\right)$ for the "urban mix" does not (and mathematically should not) equal the weighted average of the gasoline and diesel calculations.

Three possible conclusions are drawn from the lack of agreement between the calculated $P(\mathrm{SOA}) / P\left(\mathrm{O}_{\mathrm{x}}\right)$ values and the observed range in $\left.\Delta[\mathrm{OOA}] / \Delta\left[\mathrm{O}_{\mathrm{x}}\right]: 1\right)$ there are unmeasured SOA precursors (possibly including non-vehicular sources) beyond those quantified in diesel and gasoline exhaust, 2) the vehicles studied by Schauer et al. $(1999,2002)$ do not reflect the vehicle fleet in Mexico City or Houston, and 3) SOA formation from diesel exhaust cannot accurately be treated using this formulation of SOA production. These results do suggest that the $\Delta[\mathrm{OOA}] / \Delta\left[\mathrm{O}_{\mathrm{x}}\right]$ ratio in an urban area should be affected by the fuel composition of the vehicle fleet, with highest values observed in areas in which diesel fuel accounts for a large portion of total fuel use.

Measurements of the total $\mathrm{OH}$ reactivity (Shirley et al., 2006) can constrain the product of the molecular weight and SOA yield of unmeasured SOA precursors (see Supporting Information). For the calculations from 28 March 2006 in Mexico City, we calculate that this value $\left(Y \times M_{\mathrm{w}}\right)$ is $20 \mathrm{~g} / \mathrm{mol}$.

\subsection{Degree of correlation and time trends of $\Delta[\mathbf{O O A}] / \Delta\left[\mathbf{O}_{\mathrm{x}}\right]$}

In the few prior studies that have presented the relationship between OOA and $\mathrm{O}_{\mathrm{x}}$ there are a wide range of slopes and correlation values. The most relevant comparison to the PTP measurements is to the observations at the T0 supersite in Mexico City, in which $\Delta[\mathrm{OOA}] / \Delta\left[\mathrm{O}_{\mathrm{x}}\right]$ was $156 \mu \mathrm{g} \mathrm{m}^{-3} / \mathrm{ppm}$ (corrected to STP) - 31\% higher than the PTP slope - with an $R^{2}$ of 0.55 (Aiken et al., 2009). Observations of the $\Delta[\mathrm{OOA}] / \Delta\left[\mathrm{O}_{3}\right]$ ratio during a photochemically active but relatively clean time period in Pittsburgh were a relatively low $38 \mu \mathrm{g} \mathrm{m}^{-3} / \mathrm{ppm}$ (not converted to STP) (Zhang et al., 2005b), whereas $\Delta[\mathrm{OOA}] / \Delta\left[\mathrm{O}_{\mathrm{x}}\right]$ in Tokyo was $180 \mu \mathrm{g} \mathrm{m}^{-3} / \mathrm{ppm}$ with an $R^{2}$ of 0.74 (Kondo et al., 2008). Dunlea et al. (2009) present a wide range of organic aerosol $\mathrm{O}_{\mathrm{x}}$ slopes ranging from 10 to $150 \mu \mathrm{g} \mathrm{m}$ air masses at various altitudes over western North America. This range is an upper limit to the actual OOA- $\mathrm{O}_{\mathrm{x}}$ slopes, since other types of organic aerosol beyond OOA were included, but likely differ by less than $25 \%$ since most of the OA observed was highly aged.

There is considerable variation in the extent of correlation (e.g., $R^{2}$ values) observed between OOA and $\mathrm{O}_{\mathrm{x}}$ in the aforementioned studies and for the datasets shown in Fig. 2. A high degree of correlation does not necessarily indicate that the formation mechanisms of OOA and $\mathrm{O}_{\mathrm{x}}$ are actually correlated. For example, OOA and $\mathrm{O}_{\mathrm{x}}$ are highly correlated at PTP during most mornings (Herndon et al., 2008). This correlation is the result of meteorological transport and does not prove any correlation between $\mathrm{SOA}$ and $\mathrm{O}_{3}$ chemistry. PTP is above the shallow mixing layer during most nights, and during the morning upslope winds transport polluted air from below to PTP, leading to rapid increases in the concentrations of all species measured and tight correlations among all species. Similarly, the large range of pollutant concentrations observed from the C-130 aircraft can be the result of sampling air masses at varying levels of dilution, and from different source regions of various ages, as demonstrated by DeCarlo et al. (2010) for HCN and aerosol sulfate.

At PTP and at La Porte (prior to 4 September 2000), the daily increases in OOA and $\mathrm{O}_{\mathrm{x}}$ were largely the result of photochemical conversion of relatively "recent" VOC emissions on a time scale of less than $12 \mathrm{~h}$. From the preceding analysis and other studies (e.g., Weitkamp et al., 2007) it is apparent that OOA and $\mathrm{O}_{\mathrm{x}}$ are formed from separate sets of VOC precursors. The emission profiles of ozone-forming VOCs and SOA-forming VOCs are likely correlated both spatially and temporally, however, leading to the correlations observed in $[\mathrm{OOA}]$ and $\left[\mathrm{O}_{\mathrm{x}}\right]$ (Fig. 3).

The poor correlation of OOA with $\mathrm{O}_{\mathrm{x}}$ observed between 4 September and 9 September at La Porte indicates large differences in the timescales of production and loss for OOA and $\mathrm{O}_{\mathrm{x}}$. This is consistent with back-trajectories for the air masses observed at La Porte during this time period, which showed that a large portion of the PM observed was highly aged, had spent several days in transport to La Porte, and was impacted by biomass burning (Canagaratna et al., 2010), whereas most of the ozone had formed over a more recent (and shorter) time period. This is evident in the diurnal trends of OOA and $\mathrm{O}_{\mathrm{x}}$ in Fig. 2. Both OOA and $\mathrm{O}_{\mathrm{x}}$ exhibited a common diurnal pattern consisting of a daily increase starting in the morning (likely the result of photochemical production and mixing from aloft) followed by a decrease in the early evening. From 4 to 6 September 2000 there was also a steady increase of both species over several days superimposed on the diurnal trends. The "slow" multi-day increase in [OOA] was greater than the daily increases observed during the rest of the dataset, whereas this "slow" increase in $\mathrm{O}_{\mathrm{x}}$ was small compared to the daily increases, leading to an overall poor correlation between OOA and $\mathrm{O}_{\mathrm{x}}$. The correlation for individual days between 4 and 9 September 2000 (not shown) is better than that for all five days together.

The decrease in $\Delta[\mathrm{OOA}] / \Delta\left[\mathrm{O}_{\mathrm{x}}\right]$ (and $\Delta([\mathrm{SV}-$ $\mathrm{OOA}]) / \Delta\left[\mathrm{O}_{\mathrm{x}}\right]$ ) observed during several afternoons at PTP (Figs. 3 and 5) is likely caused by a combination of several factors, including increased evaporation of SV-OOA, mixing with air during boundary layer growth of variable OOA and $\mathrm{O}_{\mathrm{x}}$ levels, and a decrease in the ratio $P(\mathrm{SOA}) / P\left(\mathrm{O}_{\mathrm{x}}\right)$. The increase in ambient temperature that occurs between morning and afternoon favors partitioning of 
semivolatile compounds to the vapor phase. Dry deposition of the semivolatile organic compounds that are in equilibrium with the SOA formed would also lead to evaporation of OOA in order to re-establish equilibrium and is a potentially large sink of SOA (Dzepina et al., 2009). As shown in Fig. 5, almost all of the decrease in $\Delta[\mathrm{OOA}] / \Delta\left[\mathrm{O}_{\mathrm{x}}\right]$ is due to the decrease in $\Delta([\mathrm{SV}-\mathrm{OOA}]) / \Delta\left[\mathrm{O}_{\mathrm{x}}\right]$, where SV-OOA is the PMF component that represents the least oxidized and more volatile component of OOA. SV-OOA correlates well with nitrate aerosol (Fig. 5, $R^{2}=0.96$ on 11 and 12 March 2006), similar to observations in Pittsburgh (Ulbrich et al., 2009) (where the correlation is even better with ammonium chloride, also a semivolatile species) and in Switzerland (Lanz et al., 2007). Similar correlations between water-soluble organic carbon and nitrate were observed at the T1 site in Mexico City (Hennigan et al., 2008). The diurnal trends of [SV-OOA] and its correlation with $\mathrm{NO}_{3}^{-}\left(\mathrm{PM}_{1}\right)$ have been used as evidence of the volatility of SV-OOA since $\mathrm{NO}_{3}^{-}\left(\mathrm{PM}_{1}\right)$ is itself semivolatile (e.g., Lanz et al., 2007). Although there was increasing evaporation of ammonium nitrate during the daytime in Mexico City (Hennigan et al., 2008), evaporation of SV-OOA cannot fully account for the observed decrease in $\Delta[\mathrm{SV}-\mathrm{OOA}] / \Delta\left[\mathrm{O}_{\mathrm{x}}\right]$ at PTP. For example, on 11 and 12 March 2006 the decrease in $\Delta[\mathrm{SV}-\mathrm{OOA}] / \Delta\left[\mathrm{O}_{\mathrm{x}}\right]$ was most evident between 11:00 and 15:00 (Fig. 5). However, evaporation of ammonium nitrate and the subsequent release of gas-phase nitric acid $\left(\mathrm{HNO}_{3(\mathrm{~g})}\right)$ was minimal during these time periods: $\left[\mathrm{HNO}_{3(\mathrm{~g})}\right]$ was equal to less than $20 \%$ of $\left[\mathrm{NO}_{3}^{-}\left(\mathrm{PM}_{1}\right)\right]$ until 15:00 (Wood et al., 2009). We note that SV-OOA also correlates well with the sum of aerosol nitrate and $\mathrm{HNO}_{3}$ (not shown), a quantity that is not affected by the partitioning between condensed nitrate $\left(\mathrm{NO}_{3}^{-}\left(\mathrm{PM}_{1}\right)\right)$ and volatile nitrate $\left(\mathrm{HNO}_{3(\mathrm{~g})}\right)$. Assuming that evaporation of SOA and nitrate aerosol are contemporaneous, we conclude that evaporation of OOA (and by extension dry deposition of semivolatile organic compound vapors) accounted for a small portion of the decrease in $\Delta \mathrm{SV}-\mathrm{OOA} / \Delta \mathrm{O}_{\mathrm{x}}$ on 11 and 12 March 2006.

The initial increase in $[\mathrm{OOA}]$ vs. $\left[\mathrm{O}_{\mathrm{x}}\right]$ observed in the morning at PTP is caused by the arrival of air from below in the shallow boundary layer. The arriving polluted air mixed with air at the site with well characterized OOA and $\mathrm{O}_{\mathrm{x}}$ concentrations - typically $2 \mu \mathrm{g} / \mathrm{m}^{3}$ and $45 \mathrm{ppbv}$, respectively. The subsequent decrease in $[\mathrm{OOA}]$ and $\left[\mathrm{O}_{\mathrm{x}}\right]$ observed near 11:00 was caused by further dilution as the boundary layer continued to grow above PTP. Since the air aloft undoubtedly did not always have the same OOA and $\mathrm{O}_{\mathrm{x}}$ concentrations as those observed at PTP at night, this mixing can alter the slope of $[\mathrm{OOA}]$ vs. $\left[\mathrm{O}_{\mathrm{x}}\right]$. In the absence of detailed vertical profiles of $[\mathrm{OOA}]$ and $\left[\mathrm{O}_{\mathrm{x}}\right]$ it is difficult to quantify this effect, which could increase or decrease the value of $\Delta[\mathrm{OOA}] / \Delta\left[\mathrm{O}_{\mathrm{x}}\right]$.

A decrease in $P(\mathrm{SOA}) / P\left(\mathrm{O}_{\mathrm{x}}\right)$ is another possible explanation for the observed decrease in $[\mathrm{OOA}] /\left[\mathrm{O}_{\mathrm{x}}\right]$. Large decreases in $P(\mathrm{SOA}) / P\left(\mathrm{O}_{\mathrm{x}}\right)$ could be caused by more rapid depletion of the (unmeasured) SOA precursors than $\mathrm{O}_{3}$ precursors, a decrease in SOA yields caused by increased temperatures and/or lower $\mathrm{NO}_{\mathrm{x}}$ concentrations in the afternoon, and/or differences in the diurnal emissions profiles of both groups of precursors. The first explanation (faster depletion of SOA precursors) is certainly reasonable for large ( $>12$ carbons) alkanes (including biogenic compounds like limonene), since they are rarely measured, react faster with $\mathrm{OH}$ than smaller VOCs do, and have high aerosol formation yields (Lim and Ziemann, 2005). $\mathrm{NO}_{\mathrm{x}}$ concentrations decrease during the day due to the dilution caused by the growth of the mixing height. Although the SOA yields for many VOCs increase with decreasing $\left[\mathrm{NO}_{\mathrm{x}}\right]$ (Kroll and Seinfeld, 2008), the yields for larger VOCs (e.g., sesquiterpenes) have been shown to increase with $\left[\mathrm{NO}_{\mathrm{x}}\right](\mathrm{Ng}$ et al., 2007a). If the yields for the VOCs that are responsible for the "missing" SOA formation in Mexico City increase with $\mathrm{NO}_{\mathrm{x}}$ then a decrease in $P(\mathrm{SOA}) / P\left(\mathrm{O}_{\mathrm{x}}\right)$ would be expected to occur as boundary layer rises. The nighttime accumulation of SOA and $\mathrm{O}_{\mathrm{x}}$ precursors in the shallow urban boundary layer of Mexico City would lead also to a large decrease in $[\mathrm{SOA}] /\left[\mathrm{O}_{\mathrm{x}}\right]$ during the day if SOA precursors are consumed significantly faster than $\mathrm{O}_{\mathrm{x}}$ precursors.

\section{Conclusions}

A correlation between odd-oxygen and oxygenated organic aerosol, interpreted as secondary organic aerosol, has been observed in Mexico City and La Porte, TX. At ground sites, the correlation was strong during periods of intense photochemistry and when changes in pollutant concentrations were caused by boundary layer dynamics rather than in situ photochemistry. The ratio of $\Delta \mathrm{OOA} / \Delta \mathrm{O}_{\mathrm{x}}$ varied by a factor of 5 between the 2 locations, and was lowest during time periods in which ozone formation was dominated by oxidation of light alkenes.

Similar to other studies, efforts to model the $\Delta \mathrm{OOA} / \Delta \mathrm{O}_{\mathrm{x}}$ ratio using available $\mathrm{C}_{2}-\mathrm{C}_{12}$ VOC measurements and laboratory kinetic and yield data are low by approximately an order of magnitude, suggesting that the use of traditional SOA formation mechanisms is inappropriate for modelling atmospheric organic aerosol. Although these calculations of $P(\mathrm{SOA}) / P\left(\mathrm{O}_{\mathrm{x}}\right)$ do not reproduce the observations, the overall approach of modeling the ratio of these two photochemical products ( $\mathrm{SOA}$ and $\mathrm{O}_{3}$ ) rather than the absolute concentrations themselves may be more successful using improved formulations for the rate of SOA formation (e.g. Jimenez, 2009; Tsimpidi et al., 2010). Furthermore, the calculations using diesel and gasoline emission factors do indicate that $\Delta[\mathrm{OOA}] / \Delta\left[\mathrm{O}_{\mathrm{x}}\right]$ should be affected by the composition of an air basin's fuel consumption. Examination of whether this does indeed hold true would be an important test of SOA formation mechanisms. 
A decrease in $\Delta \mathrm{OOA} / \Delta \mathrm{O}_{\mathrm{x}}$ was frequently observed in Mexico City during the first $10 \mathrm{~h}$ of photochemistry. This can only partially be explained by evaporation of semivolatile SOA (perhaps in response to dry deposition of semivolatile organic compound vapors). More likely contributing factors are dilution with air with lower values of $[\mathrm{OOA}] /\left[\mathrm{O}_{\mathrm{x}}\right]$ and a decrease in $P(\mathrm{SOA}) / P\left(\mathrm{O}_{\mathrm{x}}\right)$ following the emission of precursors VOCs. The latter could be caused by differences in the reactivities and chemical oxidation mechanisms of SOAforming and $\mathrm{O}_{3}$-forming precursor VOCs and possibly by different emissions time trends for both sets of precursors.

\section{Supplementary material related to this article is available online at: http://www.atmos-chem-phys.net/10/8947/2010/ acp-10-8947-2010-supplement.pdf.}

Acknowledgements. This work was funded in part by NSF grants ATM-528227, ATM-0528170, ATM-0513116, and ATM-0449815, DOE grants (BER, ASP program) DE-FGO2-05ER63982, DEFGO2-05ER63980, and DE-FG02-08ER64627 and NOAA grant NA08OAR4310656. We gratefully acknowledge Linsey Marr for providing one of the chemiluminescence analyzers. We thank Manuel Quiñones of Televisa for providing power and on-site support at PTP, Rafael Ramos for logistical assistance, and Lenny Stockburger for use of the aethelometer data from La Porte. The United States Environmental Protection Agency through its Office of Research and Development collaborated in the research described here. It has been subjected to Agency review and approved for publication.

Edited by: S. Madronich

\section{References}

Aiken, A. C., DeCarlo, P. F., Kroll, J. H., Worsnop, D. R., Huffman, J. A., Docherty, K., Ulbrich, I. M., Mohr, C., Kimmel, J. R., Sueper, D., Zhang, Q., Sun, Y., Trimborn, A., Northway, M., Ziemann, P. J., Canagaratna, M. R., Onasch, T. B., Alfarra, R., Prevot, A. S. H., Dommen, J., Duplissy, J., Metzger, A., Baltensperger, U., and Jimenez, J. L.: O/C and OM/OC Ratios of Primary, Secondary, and Ambient Organic Aerosols with High Resolution Time-of-Flight Aerosol Mass Spectrometery, Environ. Sci. Technol., 42, 4478-4485, 2008.

Aiken, A. C., de Foy, B., Wiedinmyer, C., DeCarlo, P. F., Ulbrich, I. M., Wehrli, M. N., Szidat, S., Prevot, A. S. H., Noda, J., Wacker, L., Volkamer, R., Fortner, E., Wang, J., Laskin, A., Shutthanandan, V., Zheng, J., Zhang, R., Paredes-Miranda, G., Arnott, W. P., Molina, L. T., Sosa, G., Querol, X., and Jimenez, J. L.: Mexico city aerosol analysis during MILAGRO using high resolution aerosol mass spectrometry at the urban supersite (T0) - Part 2: Analysis of the biomass burning contribution and the non-fossil carbon fraction, Atmos. Chem. Phys., 10, 5315-5341, doi:10.5194/acp-10-5315-2010, 2010.

Aiken, A. C., Salcedo, D., Cubison, M. J., Huffman, J. A., DeCarlo, P. F., Ulbrich, I. M., Docherty, K. S., Sueper, D., Kimmel, J. R., Worsnop, D. R., Trimborn, A., Northway, M., Stone, E. A.,
Schauer, J. J., Volkamer, R. M., Fortner, E., de Foy, B., Wang, J., Laskin, A., Shutthanandan, V., Zheng, J., Zhang, R., Gaffney, J., Marley, N. A., Paredes-Miranda, G., Arnott, W. P., Molina, L. T., Sosa, G., and Jimenez, J. L.: Mexico City aerosol analysis during MILAGRO using high resolution aerosol mass spectrometry at the urban supersite (T0) - Part 1: Fine particle composition and organic source apportionment, Atmos. Chem. Phys., 9, 66336653, doi:10.5194/acp-9-6633-2009, 2009.

Apel, E. C., Emmons, L. K., Karl, T., Flocke, F., Hills, A. J., Madronich, S., Lee-Taylor, J., Fried, A., Weibring, P., Walega, J., Richter, D., Tie, X., Mauldin, L., Campos, T., Weinheimer, A., Knapp, D., Sive, B., Kleinman, L., Springston, S., Zaveri, R., Ortega, J., Voss, P., Blake, D., Baker, A., Warneke, C., Welsh-Bon, D., de Gouw, J., Zheng, J., Zhang, R., Rudolph, J., Junkermann, W., and Riemer, D. D.: Chemical evolution of volatile organic compounds in the outflow of the Mexico City Metropolitan area, Atmos. Chem. Phys., 10, 2353-2375, doi:10.5194/acp-10-23532010, 2010.

Arey, J., Aschmann, S. M., Kwok, E. S., and Atkinson, R.: Alkyl nitrate, hydroxyalkyl nitrate, and hydroxycarbonyl formation from the $\mathrm{NO}_{\mathrm{x}}$-air photooxidations of $\mathrm{C}_{5}-\mathrm{C}_{8}$ n-alkanes, J. Phys. Chem. A, 105, 1020-1027, 2001.

Atkinson, R.: Gas-phase tropospheric chemistry of organic compounds, Journal of Physical Chemistry Ref. Data, M2, 1994.

Atkinson, R.: Atmospheric Chemistry of VOCs and $\mathrm{NO}_{\mathrm{x}}$, Atmos. Environ., 34, 2063-2101, 2000.

Ban-Weiss, G. A., McLaughlin, J. P., Harley, R. A., Kean, A. J., Grosjean, E., and Grosjean, D.: Carbonyl and Nitrogen Dioxide Emissions from Gasoline- and Diesel-Powered Motor Vehicles, Environ. Sci. Technol., 42, 3944-3950, 2008.

Canagaratna, M. R., Jayne, J. T., Jimenez, J. L., Allan, J. D., Alfarra, M. R., Zhang, Q., Onasch, T. B., Drewnick, F., Coe, H., Middlebrook, A., Delia, A., Williams, L. R., Trimborn, A. M., Northway, M. J., DeCarlo, P. F., Kolb, C. E., Davidovits, P., and Worsnop, D. R.: Chemical and microphysical characterization of ambient aerosols with the Aerodyne Aerosol Mass Spectrometer, Mass Spectrom. Rev., 26, 185-222, doi:10.1002/mas.20115, 2007.

Canagaratna, M., Jimenez, J., Silva, P., et al.: Identification of organic aerosol sources in Houston during the TEXAQS 2000 air quality study, in preparation, 2010.

Carlton, A. G., Wiedinmyer, C., and Kroll, J. H.: A review of Secondary Organic Aerosol (SOA) formation from isoprene, Atmos. Chem. Phys., 9, 4987-5005, doi:10.5194/acp-9-4987-2009, 2009.

Cazorla, M. and Brune, W. H.: Measurement of Ozone Production Sensor, Atmos. Meas. Tech., 3, 545-555, doi:10.5194/amt3-545-2010, 2010.

Chung, M. Y.: An investigation of the relationship between total non-methane organic carbon and the sum of speciated hydrocarbons and carbonyls measured by standard GC/FID: measurements in the Los Angeles air basin, Atmos. Environ., 37, S159S170, 2003.

de Gouw, J. and Jimenez, J.: Organic Aerosols in the Earth's Atmosphere, Environ. Sci. Technol., 43(20), 7614-8211, 2009.

de Gouw, J. A., Middlebrook, A. M., Warneke, C., Goldan, P. D., Kuster, W. C., Roberts, J. M., Fehsenfeld, F. C., Worsnop, D. R., Canagaratna, M. R., Pszenny, A. A. P., Keene, W. C., Marchewka, M., Bertman, S. B., and Bates, T. S.: Budget of 
organic carbon in a polluted atmosphere: Results from the New England Air Quality Study in 2002, J. Geophys. Res.-Atmos., 110, D16305, doi:10.1029/2004JD005623, 2005.

de Gouw, J. A., Warneke, C., Stohl, A., Wollny, A. G., Brock, C. A., Cooper, O. R., Holloway, J. S., Trainer, M., Fehsenfeld, F. C., Atlas, E. L., Donnelly, S. G., Stroud, V., and Lueb, A.: Volatile organic compound composition of merged and aged forest fires from Alaska and Western Canada, J. Geophys. Res., 111, D10303, doi:10.1029/2005JD006175, 2006.

de Gouw, J. A., Welsh-Bon, D., Warneke, C., Kuster, W. C., Alexander, L., Baker, A. K., Beyersdorf, A. J., Blake, D. R., Canagaratna, M., Celada, A. T., Huey, L. G., Junkermann, W., Onasch, T. B., Salcido, A., Sjostedt, S. J., Sullivan, A. P., Tanner, D. J., Vargas, O., Weber, R. J., Worsnop, D. R., Yu, X. Y., and Zaveri, R.: Emission and chemistry of organic carbon in the gas and aerosol phase at a sub-urban site near Mexico City in March 2006 during the MILAGRO study, Atmos. Chem. Phys., 9, 3425-3442, doi:10.5194/acp-9-3425-2009, 2009.

DeCarlo, P. F., Kimmel, J. R., Trimborn, A., Northway, M. J., Jayne, J. T., Aiken, A. C., Gonin, M., Fuhrer, K., Horvath, T., Docherty, K. S., Worsnop, D. R., and Jimenez, J. L.: Field-deployable, high-resolution, time-of-flight aerosol mass spectrometer, Anal. Chem., 78, 8281-8289, 2006.

DeCarlo, P. F., Dunlea, E. J., Kimmel, J. R., Aiken, A. C., Sueper, D., Crounse, J., Wennberg, P. O., Emmons, L., Shinozuka, Y., Clarke, A., Zhou, J., Tomlinson, J., Collins, D. R., Knapp, D., Weinheimer, A. J., Montzka, D. D., Campos, T., and Jimenez, J. L.: Fast airborne aerosol size and chemistry measurements above Mexico City and Central Mexico during the MILAGRO campaign, Atmos. Chem. Phys., 8, 4027-4048, doi:10.5194/acp8-4027-2008, 2008.

DeCarlo, P. F., Ulbrich, I. M., Crounse, J., de Foy, B., Dunlea, E. J., Aiken, A. C., Knapp, D., Weinheimer, A. J., Campos, T., Wennberg, P. O., and Jimenez, J. L.: Investigation of the sources and processing of organic aerosol over the Central Mexican Plateau from aircraft measurements during MILAGRO, Atmos. Chem. Phys., 10, 5257-5280, doi:10.5194/acp-10-52572010, 2010.

Docherty, K. S., Stone, E. A., Ulbrich, I. M., DeCarlo, P. F., Snyder, D. C., Schauer, J. J., Peltier, R. E., Weber, R. J., Murphy, S. M., Seinfeld, J. H., Grover, B. D., Eatough, D. J., and Jimenez, J. L.: Apportionment of Primary and Secondary Organic Aerosols in Southern California during the 2005 Study of Organic Aerosols in Riverside (SOAR), Environ. Sci. Technol., 42, 7655-7662, 2008.

Dunlea, E. J., DeCarlo, P. F., Aiken, A. C., Kimmel, J. R., Peltier, R. E., Weber, R. J., Tomlinson, J., Collins, D. R., Shinozuka, Y., McNaughton, C. S., Howell, S. G., Clarke, A. D., Emmons, L. K., Apel, E. C., Pfister, G. G., van Donkelaar, A., Martin, R. V., Millet, D. B., Heald, C. L., and Jimenez, J. L.: Evolution of Asian aerosols during transpacific transport in INTEX-B, Atmos. Chem. Phys., 9, 7257-7287, doi:10.5194/acp-9-7257-2009, 2009.

Dusanter, S., Vimal, D., Stevens, P. S., Volkamer, R., and Molina, L. T.: Measurements of $\mathrm{OH}$ and $\mathrm{HO}_{2}$ concentrations during the MCMA-2006 field campaign - Part 1: Deployment of the Indiana University laser-induced fluorescence instrument, Atmos. Chem. Phys., 9, 1665-1685, doi:10.5194/acp-9-1665-2009, 2009.
Dzepina, K., Volkamer, R. M., Madronich, S., Tulet, P., Ulbrich, I. M., Zhang, Q., Cappa, C. D., Ziemann, P. J., and Jimenez, J. L.: Evaluation of recently-proposed secondary organic aerosol models for a case study in Mexico City, Atmos. Chem. Phys., 9, 5681-5709, doi:10.5194/acp-9-5681-2009, 2009.

Fast, J. D., de Foy, B., Acevedo Rosas, F., Caetano, E., Carmichael, G., Emmons, L., McKenna, D., Mena, M., Skamarock, W., Tie, X., Coulter, R. L., Barnard, J. C., Wiedinmyer, C., and Madronich, S.: A meteorological overview of the MILAGRO field campaigns, Atmos. Chem. Phys., 7, 2233-2257, doi:10.5194/acp-7-2233-2007, 2007.

Forster, P., Ramaswamy, V., Artaxo, P. E., Berntsen, T., Betts, R., Fahey, D., Haywood, J., Lean, J., Lowe, D., Myhre, G., Nganga, J., Prinn, R., Raga, G., Schulz, M., and Van Dorland, R.: Changes in Atmospheric Constituents and in Radiative Forcing, Cambridge, 2007.

George, I. J., Vlasenko, A., Slowik, J. G., Broekhuizen, K., and Abbatt, J. P. D.: Heterogeneous oxidation of saturated organic aerosols by hydroxyl radicals: uptake kinetics, condensed-phase products, and particle size change, Atmos. Chem. Phys., 7, 4187-4201, doi:10.5194/acp-7-4187-2007, 2007.

Geyer, A., Alicke, B., Ackermann, R., Martinez, M., Harder, H., Brune, W., Di Carlo, P., Williams, E., Jobson, T., Hall, S., Shetter, R., and Stutz, J.: Direct observations of daytime $\mathrm{NO}_{3}$ : Implications for urban boundary layer chemistry, J. Geophys. Res., 108, 4368, doi:4310.1029/2002JD002967, 2003.

Griffin, R. J., Cocker III, D. R., Flagan, R. C., and Seinfeld, J. H.: Organic aerosol formation from the oxidation of biogenic hydrocarbons, J. Geophys. Res., 104, 3555-3567, 1999.

Hagino, H., Takada, T., Kunimi, H., and Sakamoto, K.: Characterization and source presumption of wintertime submicron organic aerosols at Saitama, Japan, using the Aerodyne aerosol mass spectrometer, Atmos. Environ., 41(39), 8834-8845, 2007.

Hallquist, M., Wenger, J. C., Baltensperger, U., Rudich, Y., Simpson, D., Claeys, M., Dommen, J., Donahue, N. M., George, C., Goldstein, A. H., Hamilton, J. F., Herrmann, H., Hoffmann, T., Iinuma, Y., Jang, M., Jenkin, M. E., Jimenez, J. L., Kiendler-Scharr, A., Maenhaut, W., McFiggans, G., Mentel, Th. F., Monod, A., Prvt, A. S. H., Seinfeld, J. H., Surratt, J. D., Szmigielski, R., and Wildt, J.: The formation, properties and impact of secondary organic aerosol: current and emerging issues, Atmos. Chem. Phys., 9, 5155-5236, doi:10.5194/acp-95155-2009, 2009.

Heald, C. L., Jacob, D. J., Park, R. J., Russell, L. M., Huebert, B. J., Seinfeld, J. H., Liao, H., and Weber, R. J.: A large organic aerosol source in the free troposphere missing from current models, Geophys. Res. Lett., 32, L18809, doi:10.1029/2005GL023831, 2005.

Hennigan, C. J., Sullivan, A. P., Fountoukis, C. I., Nenes, A., Hecobian, A., Vargas, O., Peltier, R. E., Case Hanks, A. T., Huey, L. G., Lefer, B. L., Russell, A. G., and Weber, R. J.: On the volatility and production mechanisms of newly formed nitrate and water soluble organic aerosol in Mexico City, Atmos. Chem. Phys., 8, 3761-3768, doi:10.5194/acp-8-3761-2008, 2008.

Herndon, S., Onasch, T., Wood, E. C., Kroll, J. H., Canagaratna, M., Jayne, J., Zavala, M., Knighton, W. B., Mazzoleni, C., Dubey, M. K., Ulbrich, I., Jimenez, J. L., Seila, R., de Gouw, J. A., De Foy, B., Fast, J., Molina, L., Kolb, C. E., and Worsnop, D. R.: The correlation of secondary organic aerosol 
with odd oxygen in Mexico City, Geophys. Res. Lett, 35, L15804, doi:10.1029/2008GL034058, 2008.

Hofzumahaus, A., Rohrer, F., Lu, K., Bohn, B., Brauers, T., Chang, C., Fuchs, H., Holland, F., Kita, K., Kondo, Y., Li, X., Lou, S., Shao, M., Zeng, L., Wahner, A., and Zhang, Y.: Amplified Trace Gas Removal in the Troposphere, Science, 324, 1702, doi:10.1126/science.1164566, 2009.

Izzotti, A., Parodi, S., Quaglia, A., Fare, C., and Vercelli, M.: The relationship between urban airborne pollution and shortterm mortality: quantitative and qualitative aspects., European J. Epidemiol., 16, 1027-1034, 2000.

Jaegle, L.: Ozone production in the upper troposphere and the influence of aircraft during SONEX: Approach of $\mathrm{NO}_{\mathrm{x}}$-saturated conditions, Geophys. Res. Lett, 26, 3081-3084, 1999.

Jimenez, J. L., Canagaratna, M. R., Donahue, N. M., Prevot, A. S. H., Zhang, Q., Kroll, J. H., DeCarlo, P. F., Allan, J. D., Coe, H., Ng, N. L., Aiken, A. C., Docherty, K. S., Ulbrich, I. M., Grieshop, A. P., Robinson, A. L., Duplissy, J., Smith, J. D., Wilson, K. R., Lanz, V. A., Hueglin, C., Sun, Y. L., Tian, J., Laaksonen, A., Raatikainen, T., Rautiainen, J., Vaattovaara, P., Ehn, M., Kulmala, M., Tomlinson, J. M., Collins, D. R., Cubison, M. J., Dunlea, E. J., Huffman, J. A., Onasch, T. B., Alfarra, M. R., Williams, P. I., Bower, K., Kondo, Y., Schneider, J., Drewnick, F., Borrmann, S., Weimer, S., Demerjian, K., Salcedo, D., Cottrell, L., Griffin, R., Takami, A., Miyoshi, T., Hatakeyama, S., Shimono, A., Sun, J. Y., Zhang, Y. M., Dzepina, K., Kimmel, J. R., Sueper, D., Jayne, J. T., Herndon, S. C., Trimborn, A. M., Williams, L. R., Wood, E. C., Middlebrook, A. M., Kolb, C. E., Baltensperger, U., and Worsnop, D. R.: Evolution of Organic Aerosols in the Atmosphere, Science, 326, 1525-1529, 2009.

Jobson, B. T., Berkowitz, C. M., Kuster, W. C., Goldan, P. D., Williams, E. J., Fesenfeld, F. C., Apel, E. C., Karl, T., Lonneman, W. A., and Riemer, D.: Hydrocarbon source signatures in Houston, Texas: Influence of the petrochemical industry, J. Geophys. Res.-Atmos., 109, D24305, doi:10.1029/2004JD004887, 2004.

Kanaya, Y., Fukuda, M., Akimoto, H., Takegawa, N., Komazaki, Y., Yokouchi, Y., Koike, M., and Kondo, Y.: Urban photochemistry in central Tokyo: 2. Rates and regimes of oxidant $\left(\mathrm{O}_{3}+\mathrm{NO}_{2}\right)$ production, J. Geophys. Res., 113, D06301, doi:10.1029/2007JD008671, 2008.

Kleindienst, T. E., Corse, E. W., Li, W., McIver, C. D., Conver, T. S., Edney, E. O., Driscoll, D. J., Speer, R. E., Weathers, W. S., and Tejada, S. B.: Secondary Organic Aerosol Formation from the Irradiation of Simulated Automobile Exhaust, J. Air Waste Manage. Assoc., 52, 259-272, 2002.

Kleinman, L. I.: The dependence of tropospheric ozone production rate on ozone precursors, Atmos. Environ., 39, 575-586, 2005.

Kleinman, L. I., Daum, P. H., Lee, Y. N., Nunnermacker, L. J., Springston, S. R., Weinstein-Lloyd, J., and Rudolph, J.: A comparative study of ozone production in five U.S. metropolitan areas, J. Geophys. Res.-Atmos., 110, D02301, doi:10.1029/2004JD005096, 2005.

Kleinman, L. I., Springston, S. R., Daum, P. H., Lee, Y.-N., Nunnermacker, L. J., Senum, G. I., Wang, J., Weinstein-Lloyd, J., Alexander, M. L., Hubbe, J., Ortega, J., Canagaratna, M. R., and Jayne, J.: The time evolution of aerosol composition over the Mexico City plateau, Atmos. Chem. Phys., 8, 1559-1575, doi:10.5194/acp-8-1559-2008, 2008.

Knighton, W. B., Fortner, E. C., Herndon, S. C., Wood, E. C., Cana- garatna, M., Jayne, J., Kroll, J. H., Onasch, T., Trimborn, A., Worsnop, D., and Kolb, C.: Examination of Biomass Burning Tracer Signatures in Urban Environments, EOS, Transactions, American Geophysical Union, 2007.

Kolb, C. E., Herndon, S. C., McManus, J. B., Shorter, J. H., Zahniser, M. S., Nelson, D. D., Jayne, J. T., Canagaratna, M. R., and Worsnop, D. R.: Mobile Laboratory with Rapid Response Instruments for Real-Time Measurements of Urban and Regional Trace Gas and Particulate Distributions and Emission Source Characteristics, Environ. Sci. Technol., 38, 5694-5703, 2004.

Kondo, Y., Morino, Y., Fukuda, M., Kanaya, Y., Miyazaki, Y., Takegawa, N., Tanimoto, H., McKenzie, R., Johnston, P., Blake, D., Murayama, T., and Koike, M.: Formation and transport of oxidized reactive nitrogen, ozone, and secondary organic aerosol in Tokyo, J. Geophys. Res., 113, D21310, doi:10.1029/2008JD010134, 2008.

Kovacs, T. A. and Brune, W. H.: Total OH Loss Rate Measurement, J. Atmos. Chem., 39, 105-122, 2001.

Kroll, J. H. and Seinfeld, J. H.: Chemistry of secondary organic aerosol: Formation and evolution of low-volatility organics in the atmosphere, Atmos. Environ., 42, 3593-3624, 2008.

Kuster, W. C., Jobson, B. T., Karl, T., Riemer, D., Apel, E., Goldan, P. D., and Fehsenfeld, F. C.: Intercomparison of volatile organic carbon measurement techniques and data at La Porte during the TexAQS2000 Air Quality Study, Environ. Sci. Technol., 38, 221228, 2004.

Lanz, V. A., Alfarra, M. R., Baltensperger, U., Buchmann, B., Hueglin, C., and Prvt, A. S. H.: Source apportionment of submicron organic aerosols at an urban site by factor analytical modelling of aerosol mass spectra, Atmos. Chem. Phys., 7, 15031522, doi:10.5194/acp-7-1503-2007, 2007.

Lanz, V. A., Prévôt, A. S. H., Alfarra, M. R., Mohr, C., DeCarlo, P. F., Weimer, S., Gianini, M. F. D., Hueglin, C., Schneider, J., Favez, O., D’Anna, B., George, C., and Baltensperger, U.: Characterization of aerosol chemical composition by aerosol mass spectrometry in Central Europe: an overview, Atmos. Chem. Phys. Discuss., 9, 24985-25021, doi:10.5194/acpd-924985-2009, 2009.

Lei, W., de Foy, B., Zavala, M., Volkamer, R., and Molina, L. T.: Characterizing ozone production in the Mexico City Metropoli$\tan$ Area: a case study using a chemical transport model, Atmos. Chem. Phys., 7, 1347-1366, doi:10.5194/acp-7-1347-2007, 2007.

Lewis, A. C.: A larger pool of ozone-forming carbon compounds in urban atmospheres, Nature, 405, 778-781, 2000.

Lim, Y. B. and Ziemann, P. J.: Products and mechanism of secondary organic aerosol formation from reactions of n-alkanes with $\mathrm{OH}$ radicals in the presence of $\mathrm{NO}_{\mathrm{x}}$, Environ. Sci. Technol., 39, 9229-9236, 2005.

Marley, N. A., Gaffney, J. S., Tackett, M., Sturchio, N. C., Heraty, L., Martinez, N., Hardy, K. D., Marchany-Rivera, A., Guilderson, T., MacMillan, A., and Steelman, K.: The impact of biogenic carbon sources on aerosol absorption in Mexico City, Atmos. Chem. Phys., 9, 1537-1549, doi:10.5194/acp-9-1537-2009, 2009.

McCreanor, J., Cullinan, P., Nieuwenhuijsen, M. J., Stewart-Evans, J., Malliarou, E., Jarup, L., Harrington, R., Svartengren, M., Han, I., Ohman-Strickland, P., Chung, K. F., and Zhang, J.: Respiratory Effects of Exposure to Diesel Traffic in Persons with 
Asthma, The New England Journal of Medicine, 357, 23482358, 2007.

Mohr, C., Huffman, J. A., Cubison, M. J., Aiken, A. C., Docherty, K. S., Kimmel, J. R., Ulbrich, I. M., Hannigan, M., Garcia, J., and Jimenez, J. L.: Characterization of Primary Organic Aerosol Emissions from Meat Cooking, Trash Burning, and Motor Vehicles with High-Resolution Aerosol Mass Spectrometry and Comparisons with Ambient and Chamber Observations, Environ. Sci. Technol., 43, 2444-2449, 2009.

Molina, M. J., Ivanov, A. V., Trakhtenberg, S., and Molina, L. T.: Atmospheric evolution of organic aerosol, Geophys. Res. Lett, 31, L22104, doi:10.1029/2004GL020910, 2004.

Mugica, V.: Volatile organic compounds emissions from gasoline and diesel powered vehicle, Atmosfera, 14, 29-37, 2001.

Nemitz, E., Jimenez, J. L., Huffman, J. A., Canagaratna, M. R., Worsnop, D. R., and Guenther, A. B.: An eddy-covariance system for the measurement of surface/atmosphere exchange fluxes of submicron aerosol chemical species - first application above an urban area, Environ. Sci. Technol., 42, 636-657, 2008.

Neri, F., Saita, G., and Chiofalo, S.: An accurate and straightforward approach to the line regression analysis of error-affected experimental data, J. Phys. E: Sci. Instrum., 22, 215-217, 1989.

Ng, N. L., Chhabra, P. S., Chan, A. W. H., Surratt, J. D., Kroll, J. H., Kwan, A. J., McCabe, D. C., Wennberg, P. O., Sorooshian, A., Murphy, S. M., Dalleska, N. F., Flagan, R. C., and Seinfeld, J. H.: Effect of $\mathrm{NO}_{\mathrm{x}}$ level on secondary organic aerosol (SOA) formation from the photooxidation of terpenes, Atmos. Chem. Phys., 7, 5159-5174, doi:10.5194/acp-7-5159-2007, 2007a.

Ng, N. L., Kroll, J. H., Chan, A. W. H., Chhabra, P. S., Flagan, R. C., and Seinfeld, J. H.: Secondary organic aerosol formation from m-xylene, toluene, and benzene, Atmos. Chem. Phys., 7, 3909-3922, doi:10.5194/acp-7-3909-2007, 2007 b.

Ng, N. L., Canagaratna, M. R., Zhang, Q., Jimenez, J. L., Tian, J., Ulbrich, I. M., Kroll, J. H., Docherty, K. S., Chhabra, P. S., Bahreini, R., Murphy, S. M., Seinfeld, J. H., Hildebrandt, L., Donahue, N. M., DeCarlo, P. F., Lanz, V. A., Prévôt, A. S. H., Dinar, E., Rudich, Y., and Worsnop, D. R.: Organic aerosol components observed in Northern Hemispheric datasets from Aerosol Mass Spectrometry, Atmos. Chem. Phys., 10, 46254641, doi:10.5194/acp-10-4625-2010, 2010.

Odum, J. R., Hoffmann, T., Bowman, F., Collins, D., Flagan, R. C., and Seinfeld, J. H.: Gas/particle partitioning and secondary organic aerosol yields, Environ. Sci. Technol., 30, 2580-2585, 1996.

Odum, J. R., Jungkamp, T. P. W., Griffin, R. J., Forstner, H. J. L., Flagan, R. C., and Seinfeld, J. H.: Aromatics, reformulated gasoline, and atmospheric organic aerosol formation, Environ. Sci. Technol., 31, 1890-1897, 1997.

Paatero, P. and Tapper, U.: Positive Matrix Factorization - a nonnegative factor model with optimal utilization of error-estimates of data values, Environmetrics, 5, 111-126, 1994.

Pankow, J. F.: An absorption model of gas-particle partitioning of organic compounds in the atmosphere, Atmos. Environ., 28, 185-188, 1994a.

Pankow, J. F.: An absorption model of the gas aerosol partitioning involved in the formation of secondary organic aerosol, Atmos. Environ., 28, 189-193, 1994b.

Pankow, J. F. and Asher, W. E.: SIMPOL.1: a simple group contribution method for predicting vapor pressures and en- thalpies of vaporization of multifunctional organic compounds, Atmos. Chem. Phys., 8, 2773-2796, doi:10.5194/acp-8-27732008, 2008.

Paredes-Miranda, G., Arnott, W. P., Jimenez, J. L., Aiken, A. C., Gaffney, J. S., and Marley, N. A.: Primary and secondary contributions to aerosol light scattering and absorption in Mexico City during the MILAGRO 2006 campaign, Atmos. Chem. Phys., 9, 3721-3730, doi:10.5194/acp-9-3721-2009, 2009.

Petzold, A. H. and Schoenlinner, M.: Multi-angle absorption photometery - a new method for the measurement of aerosol light absorption and atmospheric black carbon, J. Aerosol Sci., 35, 421-441, 2004.

Pope, C. A. I. and Dockery, D. W.: Health Effects of Fine Particulate Air Pollution: Lines that Connect, J. Air Waste Manage. Assoc., 56, 709-742, 2006.

Ren, X. R., Harder, H., Martinez, M., Lesher, R. L., Oliger, A., Shirley, T., Adams, J., Simpas, J. B., and Brune, W. H.: $\mathrm{HO}_{\mathrm{x}}$ concentrations and $\mathrm{OH}$ reactivity observations in New York City during PMTACS-NY2001, Atmos. Environ., 37, 3627-3637, 2003.

Ridley, B. A., Grahek, F. E., and Walega, J. G.: A small, highsensitivity, medium-response ozone detector suitable for measurements from light aircraft, J. Atmos. Ocean. Tech., 9, 142148, 1992.

Robinson, A. L., Donahue, N. M., Shrivastava, M. K., Weitkamp, E. A., Sage, A. M., Grieshop, A. P., Lane, T. E., Pierce, J. R., and Pandis, S. N.: Rethinking organic aerosols: Semivolatile emissions and photochemical aging, Science, 315, 1259-1262, 2007.

Rogers, T. M., Grimsrud, E. P., Herndon, S. C., Jayne, J. T., Kolb, C. E., Allwine, E., Westberg, H., Lamb, B. K., Zavala, M., Molina, L. T., Molina, M. J., and Knighton, W. B.: On-road measurements of volatile organic compounds in the Mexico City metropolitan area using proton transfer reaction mass spectrometry, Int. J. Mass Spectrom., 252, 26-37, 2006.

Rosen, R. S., Wood, E. C., Wooldridge, P. J., Thornton, J. A., Day, D. A., Kuster, W., Williams, E. J., Jobson, B. T., and Cohen, R. C.: Observations of total alkyl nitrates during Texas Air Quality Study 2000: Implications for $\mathrm{O}_{3}$ and alkyl nitrate photochemistry, J. Geophys. Res.-Atmos., 109, D07303, doi:10.1029/2003JD004227, 2004.

Salcedo, D., Onasch, T. B., Dzepina, K., Canagaratna, M. R., Zhang, Q., Huffman, J. A., DeCarlo, P. F., Jayne, J. T., Mortimer, P., Worsnop, D. R., Kolb, C. E., Johnson, K. S., Zuberi, B., Marr, L. C., Volkamer, R., Molina, L. T., Molina, M. J., Cardenas, B., Bernabé, R. M., Márquez, C., Gaffney, J. S., Marley, N. A., Laskin, A., Shutthanandan, V., Xie, Y., Brune, W., Lesher, R., Shirley, T., and Jimenez, J. L.: Characterization of ambient aerosols in Mexico City during the MCMA-2003 campaign with Aerosol Mass Spectrometry: results from the CENICA Supersite, Atmos. Chem. Phys., 6, 925-946, doi:10.5194/acp-6-9252006, 2006.

Salcedo, D., Onasch, T. B., Canagaratna, M. R., Dzepina, K., Huffman, J. A., Jayne, J. T., Worsnop, D. R., Kolb, C. E., Weimer, S., Drewnick, F., Allan, J. D., Delia, A. E., and Jimenez, J. L.: Technical Note: Use of a beam width probe in an Aerosol Mass Spectrometer to monitor particle collection efficiency in the field, Atmos. Chem. Phys., 7, 549-556, doi:10.5194/acp-7-549-2007, 2007.

Schauer, J. J., Kleeman, M. J., Cass, G. R., and Simoneit, B. R. T.: Measurement of emissions from air pollution sources. 2. C- 
1 through C-30 organic compounds from medium duty diesel trucks, Environ. Sci. Technol., 33, 1578-1587, 1999.

Schauer, J. J., Kleeman, M. J., Cass, G. R., and Simoneit, B. R. T.: Measurement of emissions from air pollution sources. 5. C-1-C32 organic compounds from gasoline-powered motor vehicles, Environ. Sci. Technol., 36, 1169-1180, 2002.

Seila, R. L., Main, H. H., Arriaga, J. L., Martinez, G., and Ramadan, A. B.: Atmospheric volatile organic compound measurements during the 1996 Paso del Norte Study, Sci. Total Environ., 276, 153-169, 2001.

Shaw, W. J., Pekour, M. S., Coulter, R. L., Martin, T. J., and Walters, J. T.: The daytime mixing layer observed by radiosonde, profiler, and lidar during MILAGRO, Atmos. Chem. Phys. Discuss., 7, 15025-15065, doi:10.5194/acpd-7-15025-2007, 2007.

Sheehy, P. M., Volkamer, R., Molina, L. T., and Molina, M. J.: Oxidative capacity of the Mexico City atmosphere - Part 2: A $\mathrm{RO}_{\mathrm{x}}$ radical cycling perspective, Atmos. Chem. Phys. Discuss., 8, 5359-5412, doi:10.5194/acpd-8-5359-2008, 2008.

Shirley, T. R., Brune, W. H., Ren, X., Mao, J., Lesher, R., Cardenas, B., Volkamer, R., Molina, L. T., Molina, M. J., Lamb, B., Velasco, E., Jobson, T., and Alexander, M.: Atmospheric oxidation in the Mexico City Metropolitan Area (MCMA) during April 2003, Atmos. Chem. Phys., 6, 2753-2765, doi:10.5194/acp-62753-2006, 2006.

Song, C., Zaveri, R. A., Alexander, M. L., Thornton, J. A., Madronich, S., Ortega, J. V., Zelenyuk, A., Yu, X., Laskin, A., and Maughan, D. A.: Effect of hydrophobic primary organic aerosols on secondary organic aerosol formation from ozonolysis of $\alpha$-pinene, Geophys. Res. Lett, 34, L20803, doi:10.1029/2007GL030720, 2007.

Sullivan, A. P., Weber, R. J., Clements, A. L., Turner, J. R., Bae, M. S., and Schauer, J. J.: A method for on-line measurement of water-soluble organic carbon in ambient aerosol particles: Results from an urban site, Geophys. Res. Lett., 31, L13105, doi:10.1029/2004GL019681, 2004.

Takegawa, N., Miyakawa, Y., Kondo, Y., Jimenez, J. L., Zhang, Q., Worsnop, D., and Fukuda, M.: Seasonal and Diurnal Variations of Submicron Organic Aerosols in Tokyo Observed using the Aerodyne Aerosol Mass Spectrometer (AMS), J. Geophys. Res., 111, D11206, doi:10.1029/2005JD006515, 2006.

Thornton, J. A., Wooldridge, P. J., Cohen, R. C., Martinez, M., Harder, H., Brune, W. H., Williams, E. J., Roberts, J. M., Fehsenfeld, F. C., Hall, S. R., Shetter, R. E., Wert, B. P., and Fried, A.: Ozone production rates as a function of $\mathrm{NO}_{\mathrm{x}}$ abundances and $\mathrm{HO}_{\mathrm{x}}$ production rates in the Nashville urban plume, J. Geophys. Res.-Atmos., 107, 4146, doi:10.1029/2001JD000932, 2002.

Thornton, J. A., Wooldridge, P. J., Cohen, R. C., Williams, E. J., Hereid, D., Fehsenfeld, F. C., Stutz, J., and Alicke, B.: Comparisons of in situ and long path measurements of $\mathrm{NO}_{2}$ in urban plumes, J. Geophys. Res.-Atmos., 108, 4496, doi:10.1029/2003JD003559, 2003.

Tonnesen, G. S. and Dennis, R. L.: Analysis of radical propagation efficiency to assess ozone sensitivity to hydrocarbons and $\mathrm{NO}_{\mathrm{x}}$ 2. Long-lived species as indicators of ozone concentration sensitivity, J. Geophys. Res., 105, 9227-9241, 2000.

Tsimpidi, A. P., Karydis, V. A., Zavala, M., Lei, W., Molina, L., Ulbrich, I. M., Jimenez, J. L., and Pandis, S. N.: Evaluation of the volatility basis-set approach for the simulation of organic aerosol formation in the Mexico City metropolitan area, Atmos. Chem.
Phys., 10, 525-546, doi:10.5194/acp-10-525-2010, 2010.

Ulbrich, I. M., Canagaratna, M. R., Zhang, Q., Worsnop, D. R., and Jimenez, J. L.: Interpretation of organic components from Positive Matrix Factorization of aerosol mass spectrometric data, Atmos. Chem. Phys., 9, 2891-2918, doi:10.5194/acp-9-2891-2009, 2009.

Velasco, E., Lamb, B., Westberg, H., Allwine, E., Sosa, G., ArriagaColina, J. L., Jobson, B. T., Alexander, M. L., Prazeller, P., Knighton, W. B., Rogers, T. M., Grutter, M., Herndon, S. C., Kolb, C. E., Zavala, M., de Foy, B., Volkamer, R., Molina, L. T., and Molina, M. J.: Distribution, magnitudes, reactivities, ratios and diurnal patterns of volatile organic compounds in the Valley of Mexico during the MCMA 2002 \& 2003 field campaigns, Atmos. Chem. Phys., 7, 329-353, doi:10.5194/acp-7-329-2007, 2007.

Volkamer, R., Jimenez, J. L., San Martini, F., Dzepina, K., Zhang, Q., Salcedo, D., Molina, L. T., Worsnop, D. R., and Molina, M. J.: Secondary organic aerosol formation from anthropogenic air pollution: Rapid and higher than expected, Geophys. Res. Lett., 33, L17811, doi:10.1029/2006GL026899, 2006.

Volkamer, R., Sheehy, P., Molina, L. T., and Molina, M. J.: Oxidative capacity of the Mexico City atmosphere - Part 1: A radical source perspective, Atmos. Chem. Phys., 10, 6969-6991, doi:10.5194/acp-10-6969-2010, 2010.

Volkamer, R., Ziemann, P. J., and Molina, M. J.: Secondary Organic Aerosol Formation from Acetylene $\left(\mathrm{C}_{2} \mathrm{H}_{2}\right)$ : seed effect on SOA yields due to organic photochemistry in the aerosol aqueous phase, Atmos. Chem. Phys., 9, 1907-1928, doi:10.5194/acp9-1907-2009, 2009.

Weitkamp, E. A., Sage, A. M., Pierce, J. R., Donahue, N. M., and Robinson, A. L.: Organic Aerosol Formation from Photochemical Oxidation of Diesel Exhaust in a Smog Chamber, Environ. Sci. Technol., 41, 6969-6975, 2007.

WHO: Health Aspects of Air Pollution with Particulate Matter, Ozone and Nitrogen Dioxide, Bonn, 2003.

Williams, E. J.: Variations in $\mathrm{NO}_{\mathrm{y}}$ composition at Idaho Hill, Colorado, J. Geophys. Res.-Atmos., 102, 6297-6314, 1997.

Wood, E. C., Herndon, S. C., Onasch, T. B., Kroll, J. H., Canagaratna, M. R., Kolb, C. E., Worsnop, D. R., Neuman, J. A., Seila, R., Zavala, M., and Knighton, W. B.: A case study of ozone production, nitrogen oxides, and the radical budget in Mexico City, Atmos. Chem. Phys., 9, 2499-2516, doi:10.5194/acp-9-2499-2009, 2009.

Zavala, M., Herndon, S. C., Wood, E. C., Onasch, T. B., Knighton, W. B., Marr, L. C., Kolb, C. E., and Molina, L. T.: Evaluation of mobile emissions contributions to Mexico City's emissions inventory using on-road and cross-road emission measurements and ambient data, Atmos. Chem. Phys., 9, 6305-6317, doi:10.5194/acp-9-6305-2009, 2009.

Zhang, Q., Alfarra, M. R., Worsnop, D. R., Allan, J. D., Coe, H., Canagaratna, M. R., and Jimenez, J. L.: Deconvolution and quantification of hydrocarbon-like and oxygenated organic aerosols based on aerosol mass spectrometry, Environ. Sci. Technol., 39, 4938-4952, 2005a.

Zhang, Q., Worsnop, D. R., Canagaratna, M. R., and Jimenez, J. L.: Hydrocarbon-like and oxygenated organic aerosols in Pittsburgh: insights into sources and processes of organic aerosols, Atmos. Chem. Phys., 5, 3289-3311, doi:10.5194/acp-5-32892005, 2005b. 
Zhang, Q., Jimenez, J. L., Canagaratna, M. R., Allan, J. D., Coe, H., Ulbrich, I., Alfarra, M. R., Takami, A., Middlebrook, A. M., Sun, Y. L., Dzepina, K., Dunlea, E., Docherty, K., DeCarlo, P. F., Salcedo, D., Onasch, T., Jayne, J. T., Miyoshi, T., Shimono, A., Hatakeyama, S., Takegawa, N., Kondo, Y., Schneider, J., Drewnick, F., Borrmann, S., Weimer, S., Demerjian, K., Williams, P., Bower, K., Bahreini, R., Cottrell, L., Griffin, R. J.,
Rautiainen, J., Sun, J. Y., Zhang, Y. M., and Worsnop, D. R.: Ubiquity and dominance of oxygenated species in organic aerosols in anthropogenically-influenced Northern Hemisphere midlatitudes, Geophys. Res. Lett., 34, L13801, doi:10.1029/2007GL029979, 2007. 